\title{
Secondary Sulfate Minerals from Thallium Mineralized Areas: Their Formation and Environmental Significance
}

\author{
Fengqi Zhao ${ }^{1}$ and Shangyi Gu ${ }^{1,2, *(D)}$ \\ 1 College of Resource and Environmental Engineering, Guizhou University, Guiyang 550025, China; \\ gs.fqzhao21@gzu.edu.cn \\ 2 Key Laboratory of Karst Geo-Resources and Environment, Guizhou University, Guiyang 550025, China \\ * Correspondence: sygu@gzu.edu.cn
}

Citation: Zhao, F.; Gu, S. Secondary Sulfate Minerals from Thallium Mineralized Areas: Their Formation and Environmental Significance. Minerals 2021, 11, 855. https:// doi.org/10.3390/min11080855

Academic Editors: Ruggero

Vigliaturo, Giancarlo Della Ventura, Terri-Ann Berry and Elena Belluso

Received: 23 June 2021

Accepted: 4 August 2021

Published: 8 August 2021

Publisher's Note: MDPI stays neutral with regard to jurisdictional claims in published maps and institutional affiliations.

Copyright: (c) 2021 by the authors. Licensee MDPI, Basel, Switzerland. This article is an open access article distributed under the terms and conditions of the Creative Commons Attribution (CC BY) license (https:// creativecommons.org/licenses/by/ $4.0 /)$.

\begin{abstract}
Thallium is a highly toxic metal and is predominantly hosted by sulfides associated with low-temperature hydrothermal mineralization. Weathering and oxidation of sulfides generate acid drainage with a high concentration of thallium, posing a threat to surrounding environments. Thallium may also be incorporated into secondary sulfate minerals, which act as temporary storage for thallium. We present a state-of-the-art review on the formation mechanism of the secondary sulfate minerals from thallium mineralized areas and the varied roles these sulfate minerals play in Tl mobility. Up to 89 independent thallium minerals and four unnamed thallium minerals have been documented. These thallium minerals are dominated by $\mathrm{Tl}$ sulfosalts and limited to several sites. Occurrence, crystal chemistry, and $\mathrm{Tl}$ content of the secondary sulfate minerals indicate that $\mathrm{Tl}$ predominantly occurs as $\mathrm{Tl}(\mathrm{I})$ in K-bearing sulfate. Lanmuchangite acts as a transient source and sink of $\mathrm{Tl}$ for its water-soluble feature, whereas dorallcharite, Tl-voltaite, and Tl-jarosite act as the long term source and sink of $\mathrm{Tl}$ in the surface environments. Acid and/or ferric iron derived from the dissolution of sulfate minerals may increase the pyrite oxidation process and $\mathrm{Tl}$ release from Tl-bearing sulfides in the long term.
\end{abstract}

Keywords: thallium; pyrite; acid mine drainage; secondary sulfate minerals; environmental significance

\section{Introduction}

Thallium (Tl) is a typical heavy metal element with high toxicity and is listed as a priority pollutant by the United States Environmental Protection Agency (USEPA). Human exposure to $\mathrm{Tl}$ leads to acute toxicity or chronic toxicity dependent upon uptake dosage. Kidneys, lungs, heart, and nerve damage have been reported by acute toxicity of T1 [1]. Eighty-seven chronic Tl poisoning cases occurred in the 1960s in a Chinese valley with hair loss, loss of appetite, and pain in the lower extremities as typical symptoms [2]. In recent years, occasional $\mathrm{Tl}$ pollution events have been reported in China and Italy [3]. It is suggested that mining and processing of Tl-bearing sulfide ores has become a predominant source of $\mathrm{Tl}$ pollution in ecosystems [4-6].

Despite its extreme biotoxicity, $\mathrm{Tl}$ is currently still utilized in some high-tech fields (e.g., semiconductors, superconductors, and optical fibers, etc.) in an irreplaceable way [7]. The global $\mathrm{Tl}$ deposits widely occur and can be categorized into three types according to their genesis. The first type is associated with Carlin-type gold deposits, distributed in Carlin gold deposits in Nevada, the USA, and Lanmuchang Hg-Tl-Au deposit in Guizhou Province, China. The second type is associated with As and $\mathrm{Sb}$ mineralization, and is distributed in North Macedonia, Switzerland, and France [8-12]. The third one is related to $\mathrm{Zn}-\mathrm{Pb}$ mineralization, such as in Lanping $\mathrm{Zn}-\mathrm{Pb}$ deposit. Thallium mineralization in the deposits is formed in low-temperature conditions, and $\mathrm{Tl}$ is mainly hosted by sulfide minerals, e.g., lorandite, carlinite, and pyrite [13-17]. To date, 63 thallium sulfide or 
sulfosalt minerals have been documented in the literature. Moreover, scarce thallium selenide minerals were also reported [18].

In spite of the occurrence of diverse independent $\mathrm{Tl}$ minerals, the ubiquitous pyrite in hydrothermal deposits has also been reported to exhibit strikingly high $\mathrm{Tl}$ content at several sites in China and Spain [19-24], especially in independent $\mathrm{Tl}$ deposits (e.g., Lanmuchang and Xiangquan in China) [21,23], as well as in numerous Tl-bearing deposits (e.g., Yunfu and Jinding in China, McArthur River in Australia, and Bathurst Mining Camp in Canada) [25-28] where pyrite is the most important ore mineral. Unfortunately, oxidation and dissolution of these $\mathrm{Tl}$ sulfide minerals, particularly pyrite, will generate acid mine drainage (AMD) and mobilize large amounts of sequestered heavy metals. Thus, it raises concern about potential $\mathrm{Tl}$ exposure risk in the $\mathrm{Tl}$ mineralization areas.

Microbial-mediated sulfide minerals oxidation is responsible for the generation of AMD, which is characterized by low $\mathrm{pH}$ value and high load of sulfate and trace metals. As it more abundantly occurs and has a higher S/metal molar ratio than other sulfides, pyrite acts as the predominant AMD producer. Metals liberated by sulfide oxidation and dissolution may keep soluble in the AMD or precipitate locally as sulfate minerals (hereafter referring to secondary sulfate minerals). The formation and dissolution of the secondary sulfate minerals exert an important impact on the storage and transport of $\mathrm{Tl}$ and other heavy metals following weathering and oxidation of sulfide minerals. In addition, the composition of the secondary sulfate minerals could provide information about the formation condition and water-rock reaction process [29].

This paper aims to summarize the thallium deposits and minerals and crystal chemistry, field occurrence, formation, and environmental significance of secondary sulfate minerals associated to $\mathrm{Tl}$ mineralization areas. The solubility and $\mathrm{Tl}$ content of the secondary sulfate minerals are the important aspects for the sequestration and migration of $\mathrm{Tl}$ in supergene environments, which is essentially constrained by the crystal chemistry of the metal sulfate that results from AMD reaction with gangue minerals in various mineralized backgrounds. Therefore, Tl cycling constrained by secondary sulfate minerals will contribute new insights into the control of $\mathrm{Tl}$ pollution derived from $\mathrm{Tl}$ sulfide mining and processing.

\section{Thallium Ore Deposits and T1 Minerals}

\subsection{Thallium Ore Deposits}

Thallium deposits occur in diverse geological environments and countries (Figure 1). Carlin-type gold deposit, characterized by $\mathrm{Au}-\mathrm{Tl}-\mathrm{As}-\mathrm{Hg}-\mathrm{Sb}$ geochemical signature, was first reported containing high $\mathrm{Tl}$ concentrations in mineralized rocks. Thallium has been proposed as a more useful indicating element than gold in finding this type of gold deposit [8] Carlin-type gold deposits have become chief gold sources and are mainly distributed in Nevada State in the USA and southwest China [30]. Thallium in the ores is mainly hosted by independent thallium minerals (e.g., lorandite, carlinite, galkhaite, and hutchinsonite) or incorporated into pyrite, orpiment, or other sulfides [19]. Lanmuchang $\mathrm{Hg}-\mathrm{Tl}-\mathrm{Au}$ deposit in southwest China is the first reported independent Tl deposit in the world [31]. The additional small size of Carlin-type deposits are also found in Canada, the Republic of North Macedonia, Russia, Southern Tienshan Belt (including Uzbekistan, Tajikistan, Kyrgyzstan, and China), Indonesia, and Malaysia [6,30,32-34]. Given the widespread distribution of the Carlin-type gold deposits, Tl mineralization areas associated with gold, antimony, and mercury are supposed to become the global important $\mathrm{Tl}$ ore deposit occurrences.

The metamorphic-hosted deposits represent the second important thallium occurrence documented in the literature. Typical deposits include Apuan Alps; Tuscany in Italy [35], Lengenbach in Switzerland; and Yunfu in Guangdong, China [12,36]. This type of Tl deposit shares the elemental assemblage of $\mathrm{Tl}-\mathrm{Hg}-\mathrm{As}-\mathrm{Sb}-\mathrm{Pb}-\mathrm{Zn}$ in ore geochemistry. The primary Tl-bearing phases are pyrite and the complex sulfosalt due to the metamorphic remobilization of $\mathrm{Tl}$ [37]. Both Apuan Alps and Lengenbach are well known for the Tl-bearing sulfosalts and sulfides [37,38]. 
Mississippi Valley Type zinc-lead deposits have emerged as a new type of Tl-bearing sulfide deposit reported in Yunnan Lanping and Anhui Xiangquan of China [19,22]. The mineralized wall rock is carbonate rock (e.g., Xiangquan) or gypsum-bearing sandstone (e.g., Lanping). $\mathrm{Zn}-\mathrm{Pb}-\mathrm{Tl}-\mathrm{Ba}-\mathrm{Sr}$ characterizes the element assemblage, with pyrite being the prevailing Tl-bearing mineral, and less common, lorandite and raguinite [39,40]. Skrikerum $\mathrm{Cu}-\mathrm{Ag}-\mathrm{Tl}-(\mathrm{Au})$ selenide deposit from SE Sweden is the only thallium selenide deposit in which thallium is mainly hosted by bukovite $\left(\mathrm{Cu}_{4} \mathrm{Tl}_{2} \mathrm{Se}_{4}\right)$ and crookesite $\left(\mathrm{Cu}_{7}(\mathrm{Tl}, \mathrm{Ag}) \mathrm{Se}_{4}\right)$ in calcite-selenide veins [18].

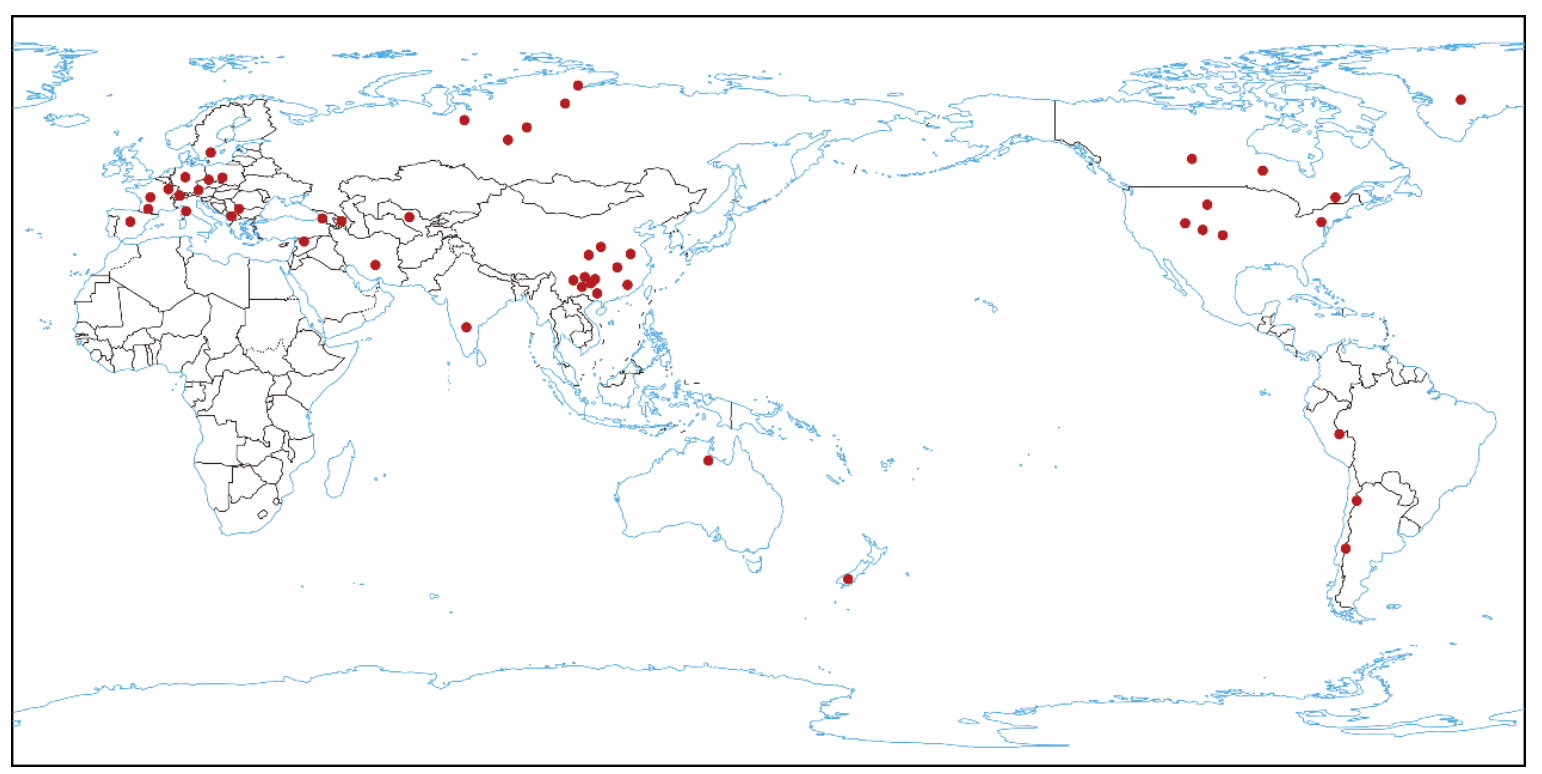

Figure 1. Tl-(bearing) deposits occurrence in the world (modified from [6,7]).

Despite the fact that Tl-(bearing) deposits are increasingly discovered in various mineralized geological settings around the world, little research has been conducted to date focusing on Tl mineralization. Apparently, almost all Tl-(bearing) deposits are associated with lowtemperature hydrothermal fluids, and $\mathrm{Tl}$ is predominantly hosted in sulfide phases. It signifies that in hydrothermal systems $\mathrm{Tl}$ shows a higher affinity for sulfur compared to potassium. To the best of our knowledge, weakly acidic Tl-rich polymetallic ore fluids originated from the deep crust are considered to be the prerequisite for Tl mineralization [41,42]. Both theoretical calculations [43] and simulation experiments [44] support that the temperature decrease, especially the effective neutralization of acidity by the host rock, are crucial factors for $\mathrm{Tl}$ precipitation from ore fluids, and field observations have also revealed extensively developed argillization from neutralizing acidic fluids in the Lanmuchang-independent Tl deposit [45] as well as $\mathrm{Tl}$ mineralisation in the Allchar Au-As-Sb-Tl deposit in North Macedonia occurring at the distal end of the hydrothermal system [46].

\subsection{Thallium Minerals}

Owing to the same charge (+1) and similar ionic radii between $\mathrm{Tl}$ and $\mathrm{K}\left(1.70 \AA\right.$ for $\mathrm{Tl}^{+}$ and $1.64 \AA$ for $\mathrm{K}^{+}$), $\mathrm{Tl}$ can be incorporated into K-bearing silicate minerals by isomorphic substitution for potassium. It is evidenced by the elevated concentration of $\mathrm{Tl}$ in mica and $\mathrm{K}$-feldspar over $20 \mathrm{ppm}$ compared to $0.7 \mathrm{ppm}$ of the crust abundance [47]. However, $\mathrm{Tl}$ also appears to have sulfur affinity for similar-sized $\mathrm{Ag}^{+}$and $\mathrm{Pb}^{2+}$ in sulfides and sulfosalts [48]. As such, $\mathrm{Tl}$ can form independent sulfide or sulfosalt minerals with $\mathrm{Pb}, \mathrm{Zn}, \mathrm{Cu}, \mathrm{As}, \mathrm{Sb}, \mathrm{Fe}$, $\mathrm{Hg}$, and $\mathrm{Au}$ in various hydrothermal processes [15].

\subsubsection{Thallium Sulfide}

Thallium sulfide mineral carlinite was first found in the Carlin gold deposit in Nevada, the USA and is named for its locality Carlin [49]. Although Tl could present as Tl(I) 
and $\mathrm{Tl}(\mathrm{III})$, carlinite $\left(\mathrm{Tl}^{+1}{ }_{2} \mathrm{~S}\right)$ is the only reported thallium sulfide mineral that occurs in Carlin gold deposit and Buus Fe-As-Tl mineralized occurrence in the Swiss Jura Mountains $[49,50]$.

\subsubsection{Thallium Sulfosalt}

Thallium sulfosalts represent the most abundant thallium minerals mainly found in hydrothermal deposits due to their complex structure, structure diversity, and the prevalence of isomorphism substitution among cations (e.g., $\mathrm{As}, \mathrm{Sb}, \mathrm{Pb}, \mathrm{Hg}, \mathrm{Ag}$ ). Sulfo-arsenite and sulfo-antimonide dominate 63 known thallium sulfosalts. Thallium sulfosalt mineralogy and crystal chemistry have been well-reviewed [51-54]. According to their structure types, seven archetypes ( $\mathrm{SnS}, \mathrm{PbS}$, sphalerite, Tl-rich structures, structures of combination of two archetypes, chain structures, and layer structures with thallium-rich layers) have been categorized, and detailed crystal structures and crystal-chemical generalizations have been made [54]. Tuscany in Italy and Lengenbach in Switzerland are two classic localities for these rare thallium sulfosalt minerals $[35,55]$. Metamorphic overprint upon previous hydrothermal deposits is responsible for the complex thallium mineralization $[55,56]$.

Lorandite $\left(\mathrm{TlAsS}_{2}\right)$ is the most common thallium sulfosalt mineral in Tajikistan, Russia, Iran, Switzerland, North Macedonia, and China in various mineralized backgrounds [57,58]. However, Allchar in Macedonia and Lanmuchang in China are two prominent concentrated localities [31,57]. Unlike common links with $\mathrm{Hg}$, As, and $\mathrm{Sb}$ mineralization, lorandite in Fengshan of Eastern China is closely associated with $\mathrm{Cu}-\mathrm{Au}$ skarn mineralization with high $\mathrm{Tl}$ concentrations (up to $2016 \mathrm{ppm}$ ) in gold ore [58].

\subsubsection{Thallium Telluride and Selenides}

Very rare thallium tellurides and selenides are documented in some sites. Honeaite $\left(\mathrm{Au}_{3} \mathrm{TlTe}_{2}\right)$ is the only reported natural thallium-bearing gold telluride [59]. These minerals are found in Karonie gold deposit, Eastern Goldfields province, Western Australia. Native gold and tellurobismuthite are common paragenetic minerals [60]. Electron-microprobe data on 17 grains of honeaite give an average $\mathrm{Tl}$ concentration of $19.46 \%$ [60]. Bukovite $\left(\mathrm{Cu}_{4} \mathrm{Tl}_{2} \mathrm{Se}_{4}\right)$, crookesite $\left(\mathrm{Cu}_{7}(\mathrm{Tl}, \mathrm{Ag}) \mathrm{Se}_{4}\right)$, and Sabatierite $\left(\mathrm{Cu}_{6} \mathrm{TlSe}_{4}\right)$ are three reported thallium selenides, which together with $\mathrm{Tl}$ tellurides, are formed in the low temperature and slightly oxidized conditions [18].

\subsubsection{Other Thallium Minerals}

Thallium halides and primary sulfates are both limited to the fumaroles. Lafossaite $(\mathrm{Tl}(\mathrm{Cl}, \mathrm{Br}))$, Nataliyamalikite (TlI), thallium-enriched flinteite $(\mathrm{K}, \mathrm{Tl})_{2} \mathrm{ZnCl}_{4}(27.7 \mathrm{wt} . \% \mathrm{Tl})$, saltonseaite $(\mathrm{K}, \mathrm{Tl})_{3} \mathrm{NaMnCl}_{6}(3.5 \mathrm{wt}$.\% $\mathrm{Tl})$, chrysothallite $\mathrm{K}_{6} \mathrm{Cu}_{6} \mathrm{Tl}^{3+} \mathrm{Cl}_{17}(\mathrm{OH})_{4} \cdot \mathrm{H}_{2} \mathrm{O}$, kalithallite $\mathrm{K}_{3} \mathrm{Tl}^{3+} \mathrm{Cl}_{6} \cdot 2 \mathrm{H}_{2} \mathrm{O}$, karpovite $\mathrm{Tl}_{2} \mathrm{VO}\left(\mathrm{SO}_{4}\right)_{2}\left(\mathrm{H}_{2} \mathrm{O}\right)$, evdokimovite $\mathrm{Tl}_{4}(\mathrm{VO})_{3}\left(\mathrm{SO}_{4}\right)_{5}\left(\mathrm{H}_{2} \mathrm{O}\right)_{5}$, and markhininite $\mathrm{TlBi}\left(\mathrm{SO}_{4}\right)_{2}$ have been discovered in the fumaroles [61-63]. It is noteworthy that chrysothallite and kalithallite are two of the three known natural minerals of $\mathrm{Tl}^{3+}$ (the third is avicennite $\mathrm{Tl}_{2} \mathrm{O}_{3}$ ), containing not only thallium but also potassium in different structural sites. Occurrences of these thallic minerals imply that there may be other mechanisms responsible for the oxidation of $\mathrm{Tl}^{+}$to $\mathrm{Tl}^{3+}$ in addition to the avicennite typically associated with manganese oxides [64,65]. However, the mechanisms for oxidation have not been elucidated yet.

$\mathrm{Pd}$ thallide $\left(\mathrm{Pd}_{3} \mathrm{Tl}\right)$ and two new $\mathrm{Pd}$ thallide phases were documented in the magmatic PGE deposit of Russia and South Africa. These Pd thallide phases occur as composite grains or intergrowths of sub-millimeter size. Post magmatic-hydrothermal fluid reaction with PGE minerals is responsible for forming these unusual PGE thallide minerals $[63,66]$.

In addition to the above-mentioned $\mathrm{Tl}$ minerals, other $\mathrm{Tl}$ minerals occur much rarer. All reported 89 thallium minerals and their chemical formula are given in Table 1. Taken together, thallium sulfosalts and monovalent thallium minerals dominate. 


\section{Secondary Sulfate Mineralogy in Tl Mineralization Areas}

The oxidation/weathering of pyrite $\left(\mathrm{FeS}_{2}\right)$ and other sulfide minerals introduces a high metal (e.g., $\mathrm{Fe}, \mathrm{Mn}, \mathrm{Tl}, \mathrm{Cu}, \mathrm{Ni}$ ) concentration and sulfate into the surrounding environment. However, the formation of secondary sulfate could critically mediate the metal releasing process due to incorporating metal and sulfate into the secondary minerals. Many of the secondary sulfate minerals are soluble in the aqueous media; they represent the transient sink for sulfate, acidity, and metals [67]. Crystal chemistry exerts the primary control for the solubility of and incorporation of metal into the minerals.

The secondary sulfate minerals in thallium deposits, including thallium sulfate and Fe- and Al-hydroxysulfate minerals, have been documented in the literature [19,68-70]. As oxidation/weathering of pyrite releases large amounts of $\mathrm{Fe}^{2+}$ and $\mathrm{SO}_{4}{ }^{2-}$ into the AMD, the melanterite group dominates the secondary sulfate with less occurrence of monovalent metal sulfates (e.g., lanmuchangite and alum), other divalent metal sulfates (e.g., gypsum and epsomite), and trivalent metal sulfates (e.g., alunogen and coquimbite).

Table 1. Independent thallium minerals.

\begin{tabular}{|c|c|c|c|}
\hline Mineral (Ref.) & Chemical Formula & Mineral (Ref.) & Chemical Formula \\
\hline Argentobaumhauerite [71] & $(\mathrm{Ag}, \mathrm{Tl})_{1.5} \mathrm{~Pb}_{22} \mathrm{As}_{33.5} \mathrm{~S}_{72}$ & Jentschite [72] & $\mathrm{TlPbAs}_{2} \mathrm{SbS}_{6}$ \\
\hline Arsiccioite [73] & $\mathrm{AgHg}_{2} \mathrm{TlAs}_{2} \mathrm{~S}_{6}$ & Kalithallite [74] & $\mathrm{K}_{3} \mathrm{Tl}^{3+} \mathrm{Cl}_{6} \cdot 2 \mathrm{H}_{2} \mathrm{O}$ \\
\hline Auerbakhite [75] & $\mathrm{MnTl}_{2} \mathrm{As}_{2} \mathrm{~S}_{5}$ & Karpovite [76] & $\mathrm{Tl}_{2} \mathrm{VO}\left(\mathrm{SO}_{4}\right)_{2}\left(\mathrm{H}_{2} \mathrm{O}\right)$ \\
\hline Avicennite [77] & $\mathrm{Tl}_{2} \mathrm{O}_{3}$ & Lafossaite [63] & $\mathrm{Tl}(\mathrm{Cl}, \mathrm{Br})$ \\
\hline Bernardite [78] & $\mathrm{Tl}(\mathrm{As}, \mathrm{Sb})_{5} \mathrm{~S}_{8}$ & Lanmuchangite [68] & $\mathrm{TlAl}\left(\mathrm{SO}_{4}\right)_{2} \cdot 12 \mathrm{H}_{2} \mathrm{O}$ \\
\hline Biagioniite [79] & $\mathrm{Tl}_{2} \mathrm{SbS}_{2}$ & Lorándite [80] & $\mathrm{TlAsS}_{2}$ \\
\hline Boscardinite [81] & $\mathrm{TlPb}_{4}\left(\mathrm{Sb}_{7} \mathrm{As}_{2}\right) \mathrm{S}_{18}$ & Markhininite [82] & $\mathrm{TlBi}\left(\mathrm{SO}_{4}\right)_{2}$ \\
\hline Bukovite [83] & $\mathrm{Cu}_{4} \mathrm{Tl}_{2} \mathrm{Se}_{4}$ & Nataliyamalikite [61] & TII \\
\hline Carlinite [49] & $\mathrm{Tl}_{2} \mathrm{~S}$ & Parapierrotite [84] & $\mathrm{Tl}(\mathrm{Sb}, \mathrm{As})_{5} \mathrm{~S}_{8}$ \\
\hline Chabournéite [85] & $\mathrm{Tl}_{4} \mathrm{~Pb}_{2}(\mathrm{Sb}, \mathrm{As})_{20} \mathrm{~S}_{34}$ & Perlialite [86] & $\mathrm{K}_{3} \mathrm{TlAl}_{3} \mathrm{Si}_{4} \mathrm{O}_{18} \cdot 5 \mathrm{H}_{2} \mathrm{O}$ \\
\hline Chalcothallite [83] & $\mathrm{Tl}_{2}(\mathrm{Cu}, \mathrm{Fe})_{6} \mathrm{SbS}_{4}$ & Philrothite [87] & $\mathrm{TlAs}_{3} \mathrm{~S}_{5}$ \\
\hline Christite [88] & $\mathrm{TlHgAsS}_{3}$ & Picotpaulite [89] & $\mathrm{TlFe}_{2} \mathrm{~S}_{3}$ \\
\hline Chrysothallite [74] & $\mathrm{K}_{6} \mathrm{Cu}_{6} \mathrm{Tl}^{3+} \mathrm{Cl}_{17}(\mathrm{OH})_{4} \cdot \mathrm{H}_{2} \mathrm{O}$ & Pierrotite [90] & $\mathrm{Tl}_{2}(\mathrm{Sb}, \mathrm{As})_{10} \mathrm{~S}_{16}$ \\
\hline Criddleite [91] & $\mathrm{TlAg}_{2} \mathrm{Au}_{3} \mathrm{Sb}_{10} \mathrm{~S}_{10}$ & Pokhodyashinite [92] & $\mathrm{Cu}_{2} \mathrm{Tl}_{3} \mathrm{Sb}_{5} \mathrm{As}_{2} \mathrm{~S}_{13}$ \\
\hline Crookesite [93] & $\mathrm{Cu}_{7}(\mathrm{Tl}, \mathrm{Ag}) \mathrm{Se}_{4}$ & Protochabournéite [94] & $\mathrm{Tl}_{2} \mathrm{~Pb}(\mathrm{Sb}, \mathrm{As})_{10} \mathrm{~S}_{17}$ \\
\hline Cuprostibite [95] & $\mathrm{Cu}_{2}(\mathrm{Sb}, \mathrm{Tl})$ & Raberite [96] & $\mathrm{Tl}_{5} \mathrm{Ag}_{4} \mathrm{As}_{6} \mathrm{SbS}_{15}$ \\
\hline Dalnegroite [97] & $\mathrm{Tl}_{4} \mathrm{~Pb}_{2} \mathrm{Sb}_{8} \mathrm{As}_{12} \mathrm{~S}_{34}$ & Raguinite [98] & $\mathrm{TlFeS}_{2}$ \\
\hline Dekatriasartorite [99] & $\mathrm{TlPb}_{58} \mathrm{As}_{97} \mathrm{~S}_{204}$ & Ralphcannonite [100] & $\mathrm{AgZn} \mathrm{TlAs}_{2} \mathrm{~S}_{6}$ \\
\hline Dorallcharite [101] & $\mathrm{TlFe}_{3}\left(\mathrm{SO}_{4}\right)_{2}(\mathrm{OH})_{6}$ & Rathite [102] & $\mathrm{Ag}_{2} \mathrm{~Pb}_{12-\mathrm{x}} \mathrm{Tl}_{\mathrm{x} / 2} \mathrm{As}_{18+x / 2} \mathrm{~S}_{40}$ \\
\hline Drechslerite [103] & $\mathrm{Tl}_{4}\left(\mathrm{Sb}_{4-\mathrm{x}} \mathrm{As}_{\mathrm{x}}\right) \mathrm{S}_{8}$ & Rayite [104] & $(\mathrm{Ag}, \mathrm{Tl})_{2} \mathrm{~Pb}_{8} \mathrm{Sb}_{8} \mathrm{~S}_{21}$ \\
\hline Écrinsite [105] & $\mathrm{AgTl}_{3} \mathrm{~Pb}_{4} \mathrm{As}_{11} \mathrm{Sb}_{9} \mathrm{~S}_{36}$ & Rebulite [106] & $\mathrm{Tl}_{5} \mathrm{Sb}_{5} \mathrm{As}_{8} \mathrm{~S}_{22}$ \\
\hline Edenharterite [107] & $\mathrm{TlPbAs}_{3} \mathrm{~S}_{6}$ & Richardsollyite [108] & $\mathrm{TlPbAsS}_{3}$ \\
\hline Ellisite [109] & $\mathrm{Tl}_{3} \mathrm{AsS}_{3}$ & Rohaite [83] & $\mathrm{TlCu}_{5} \mathrm{SbS}_{2}$ \\
\hline Erniggliite [110] & $\mathrm{Tl}_{2} \mathrm{SnAs}_{2} \mathrm{~S}_{6}$ & Routhierite [111] & $\mathrm{TlCuHg}_{2} \mathrm{As}_{2} \mathrm{~S}_{6}$ \\
\hline Enneasartorite [112] & $\mathrm{Tl}_{6} \mathrm{~Pb}_{32} \mathrm{As}_{70} \mathrm{~S}_{140}$ & Sabatierite [113] & $\mathrm{Cu}_{6} \mathrm{TlSe}_{4}$ \\
\hline Evdokimovite [114] & $\mathrm{Tl}_{4}(\mathrm{VO})_{3}\left(\mathrm{SO}_{4}\right)_{5}\left(\mathrm{H}_{2} \mathrm{O}\right)_{5}$ & Saltonseaite [115] & $(\mathrm{K}, \mathrm{Tl})_{3} \mathrm{NaMnCl}_{6}$ \\
\hline Fangite [116] & $\mathrm{Tl}_{3} \mathrm{AsS}_{4}$ & Sicherite [117] & $\mathrm{TlAg}_{2}(\mathrm{As}, \mathrm{Sb})_{3} \mathrm{~S}_{6}$ \\
\hline Ferrostalderite [118] & $\mathrm{CuFe}_{2} \mathrm{TlAs}_{2} \mathrm{~S}_{6}$ & Simonite [119] & $\mathrm{TlHgAs}_{3} \mathrm{~S}_{6}$ \\
\hline Ferrovorontsovite [120] & $\left(\mathrm{Fe}_{5} \mathrm{Cu}\right) \mathrm{TlAs}_{4} \mathrm{~S}_{12}$ & Spaltiite [121] & $\mathrm{Tl}_{2} \mathrm{Cu}_{2} \mathrm{As}_{2} \mathrm{~S}_{5}$ \\
\hline Flinteite [122] & $(\mathrm{K}, \mathrm{Tl})_{2} \mathrm{ZnCl}_{4}$ & Stalderite [123] & $\mathrm{TlCu}(\mathrm{Zn}, \mathrm{Fe}, \mathrm{Hg})_{2} \mathrm{As}_{2} \mathrm{~S}_{6}$ \\
\hline Gabrielite [124] & $\mathrm{Tl}_{2} \mathrm{AgCu}_{2} \mathrm{As}_{3} \mathrm{~S}_{7}$ & Steropesite [125] & $\mathrm{Tl}_{3} \mathrm{BiCl}_{6}$ \\
\hline Gladkovskyite [126] & $\mathrm{MnTlAs}_{3} \mathrm{~S}_{6}$ & Thalcusite [83] & $\mathrm{Tl}_{2} \mathrm{Cu}_{3} \mathrm{FeS}_{4}$ \\
\hline Galkhaite [120] & $\mathrm{Tl}(\mathrm{Hg}, \mathrm{Cu}, \mathrm{Zn})_{6}(\mathrm{As}, \mathrm{Sb})_{4} \mathrm{~S}_{12}$ & Thalfenisite [127] & $\mathrm{Tl}_{6}(\mathrm{Fe}, \mathrm{Ni}, \mathrm{Cu})_{25} \mathrm{~S}_{26} \mathrm{Cl}$ \\
\hline Gillulyite [116] & $\mathrm{Tl}_{2}(\mathrm{As}, \mathrm{Sb})_{8} \mathrm{~S}_{13}$ & Thalliomelane [103] & $\mathrm{TlMn}^{4+}{ }_{75} \mathrm{Cu}^{2+} 0_{5} \mathrm{O}_{16}$ \\
\hline Gungerite [128] & $\mathrm{TlAs}_{5} \mathrm{Sb}_{4} \mathrm{~S}_{13}$ & Thalliumpharmacosiderite [121] & $\mathrm{TlFe}_{4}\left[\left(\mathrm{AsO}_{4}\right)_{3}(\mathrm{OH}) 4\right] \cdot 4 \mathrm{H}_{2} \mathrm{O}$ \\
\hline Hatchite [129] & $\mathrm{AgTlPbAs}_{2} \mathrm{~S}_{5}$ & Thunderbayite [130] & $\mathrm{TlAg}_{3} \mathrm{Au}_{3} \mathrm{Sb}_{7} \mathrm{~S}_{6}$ \\
\hline Hendekasartorite [112] & $\mathrm{Tl}_{2} \mathrm{~Pb}_{48} \mathrm{As}_{82} \mathrm{~S}_{172}$ & Tsygankoite [131] & $\mathrm{Mn}_{8} \mathrm{Tl}_{8} \mathrm{Hg}_{2}\left(\mathrm{Sb}_{21} \mathrm{~Pb}_{2} \mathrm{Tl}\right) \mathrm{S}_{48}$ \\
\hline Hephaistosite [62] & $\mathrm{TlPb}_{2} \mathrm{Cl}_{5}$ & Twinnite [132] & $\mathrm{Pb}_{0.8} \mathrm{Tl}_{0.1} \mathrm{Sb}_{1.3} \mathrm{As}_{0.8} \mathrm{~S}_{4}$ \\
\hline Heptasartorite [112] & $\mathrm{Tl}_{7} \mathrm{~Pb}_{22} \mathrm{As}_{55} \mathrm{~S}_{108}$ & Vaughanite [133] & $\mathrm{TlHgSb}_{4} \mathrm{~S}_{7}$ \\
\hline Honeaite [60] & $\mathrm{Au}_{3} \mathrm{TlTe}_{2}$ & Voltaite [35] & $(\mathrm{K}, \mathrm{Tl})_{2} \mathrm{Fe}_{8} \mathrm{Al}\left(\mathrm{SO}_{4}\right)_{12} \cdot 18 \mathrm{H}_{2} \mathrm{O}$ \\
\hline Hutchinsonite [134] & $(\mathrm{Pb}, \mathrm{Tl})_{2} \mathrm{As}_{5} \mathrm{~S}_{9}$ & Vorontsovite [120] & $\left(\mathrm{Hg}_{5} \mathrm{Cu}\right) \mathrm{TlAs}_{4} \mathrm{~S}_{12}$ \\
\hline Imhofite [135] & $\mathrm{Tl}_{5.8} \mathrm{As}_{15.4} \mathrm{~S}_{26}$ & Vrbaite [136] & $\mathrm{Hg}_{3} \mathrm{Tl}_{4} \mathrm{As}_{8} \mathrm{Sb}_{2} \mathrm{~S}_{20}$ \\
\hline Incomsartorite [137] & $\mathrm{Tl}_{6} \mathrm{~Pb}_{144} \mathrm{As}_{246} \mathrm{~S}_{516}$ & Wallisite [138] & $\mathrm{CuPbTlAs}_{2} \mathrm{~S}_{5}$ \\
\hline Jarosite [64] & $(\mathrm{Tl}, \mathrm{K}) \mathrm{Fe}_{3}\left(\mathrm{SO}_{4}\right)_{2}(\mathrm{OH})_{6}$ & Weissbergite [139] & $\mathrm{TlSbS}_{2}$ \\
\hline Jankovicite [140] & $\mathrm{Tl}_{5} \mathrm{Sb}_{9}(\mathrm{As}, \mathrm{Sb})_{4} \mathrm{~S}_{22}$ & & \\
\hline
\end{tabular}




\subsection{Secondary Thallium and Potassium Sulfate}

The mineralogy of thallium sulfate in secondary environments of mining areas is constrained to very few species. Two $\mathrm{Tl}^{+}$-oxysalts, namely dorallcharite [101] and lanmuchangite [68], are the reported secondary sulfate minerals, with thallium occurring as a monovalent ion in the two minerals. Potassium sulfate minerals (e.g., voltaite) have elevated $\mathrm{Tl}$ contents due to the substitution of $\mathrm{K}$ by $\mathrm{Tl}$ [141]. The chemical formula, unit cell parameter, and crystal system for these two minerals and the other three thallium sulfate minerals are given in Table 2.

Table 2. Crystal chemistry for thallium sulfate minerals $[68,76,82,101,114]$.

\begin{tabular}{cccc}
\hline Mineral & Chemical Formula & Crystal System & Unit-Cell Parameters \\
\hline Lanmuchangite & $\mathrm{TlAl}_{\left(\mathrm{SO}_{4}\right)_{2} \cdot 12 \mathrm{H}_{2} \mathrm{O}}$ & Isometric & $a=12.212 \AA, V=1871 \AA^{3}$ \\
Dorallcharite & $\mathrm{TlFe}_{3}\left(\mathrm{SO}_{4}\right)_{2}(\mathrm{OH})_{6}$ & Trigonal & $a=7.3301, c=17.6631 \AA, V=821.73 \AA^{3}$, \\
Evdokimovite & $\mathrm{Tl}_{4}(\mathrm{VO})_{3}\left(\mathrm{SO}_{4}\right)_{5} \cdot\left(\mathrm{H}_{2} \mathrm{O}\right)_{5}$ & Monoclinic & $a=6.2958, b=10.110, c=39.426 \AA, V=2509.4 \AA^{3}, \beta=90.347^{\circ}$ \\
Karpovite & $\mathrm{Tl}_{2} \mathrm{VO}\left(\mathrm{SO}_{4}\right)_{2}\left(\mathrm{H}_{2} \mathrm{O}\right)$ & Monoclinic & $a=4.6524, b=11.0757, c=9.3876 \AA^{\circ}, V=478.60 \AA^{3}, \beta=98.353^{\circ}$ \\
Markhininite & $\mathrm{TlBi}\left(\mathrm{SO}_{4}\right)_{2}$ & Triclinic & $a=7.378, b=10.657, c=10.657 \AA, V=680.2 \AA^{3}, \alpha=61.31$, \\
& & & $\beta=70.964, \gamma=70.964^{\circ}$ \\
\hline
\end{tabular}

Dorallcharite $\left(\mathrm{TlFe}^{3+}{ }_{3}\left(\mathrm{SO}_{4}\right)_{2}(\mathrm{OH})_{6}\right)$ is the Tl-analog of jarosite; it was initially found in Allchar of North Macedonian and thereafter in France [142] and Switzerland [49]. The crystal structure for dorallcharite is presented in Figure 2. Dorallcharite occurs associated with gypsum, rosselrite $\left(\mathrm{MgHAsO}_{4} \cdot 7 \mathrm{H}_{2} \mathrm{O}\right)$, thalliumpharmacosiderite $\left(\mathrm{TlFe}_{4}\left[\left(\mathrm{AsO}_{4}\right)_{3}\right.\right.$ $\left.\left.(\mathrm{OH})_{4}\right] \cdot 4 \mathrm{H}_{2} \mathrm{O}\right)$, and amorphous Fe and $\mathrm{Mn}$ sulfate and/or arsenate at Allchar [101]. The mean concentration of $\mathrm{Tl}$ and $\mathrm{K}$ from 25 microprobe measurements is $23 \%$ and $1.23 \%$, respectively [143]. It is formed following $\mathrm{Tl}$ removal from sulfide oxidation and subsequently retained by the sulfate [101]. Given that $\mathrm{Tl}^{+}$substitutes $\mathrm{K}^{+}$in jarosite, a complete solid-solution series exists between jarosite and dorallcharite [101].

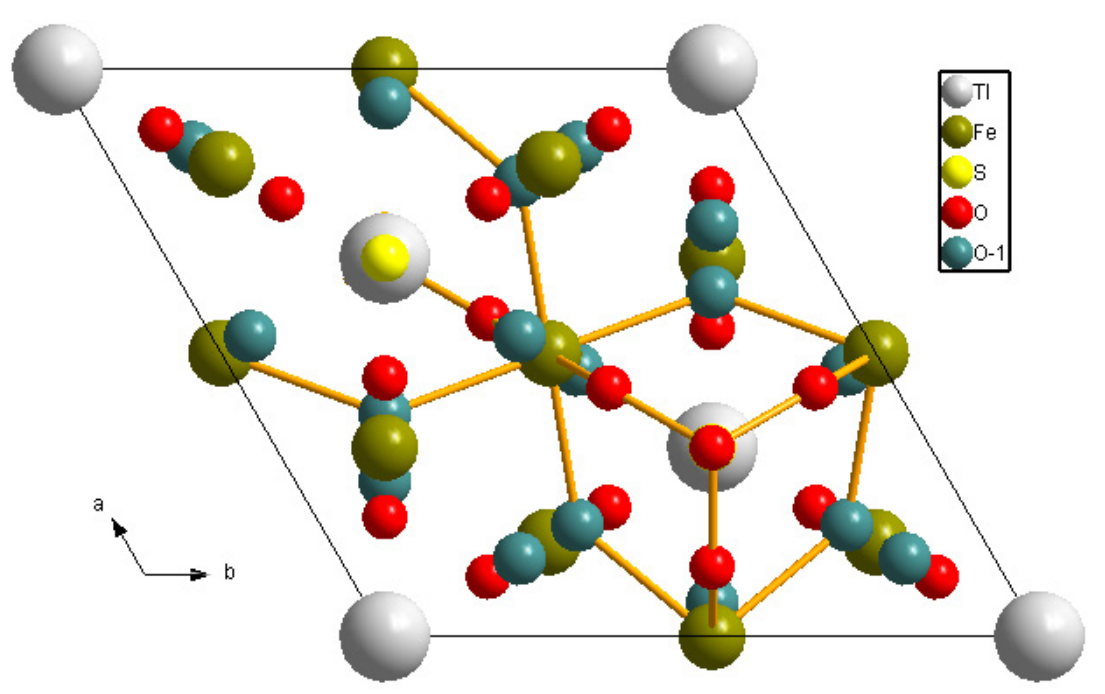

Figure 2. Crystal structure of dorallcharite.

Lanmuchangite $\left(\mathrm{TlAl}\left(\mathrm{SO}_{4}\right)_{2} \cdot 12 \mathrm{H}_{2} \mathrm{O}\right)$ is the Tl-analog of alunite. It is only reported in its type locality, China [68], which is associated with melanterite, pickeringite, alum, jarosite, gypsum, native sulfur, arsenolite, and some unknown minerals in the oxidized zone of the Lanmuchang $\mathrm{Hg}$-Tl deposit [68]. It belongs to the alum group with the general formula $\mathrm{X}^{+} \mathrm{Al}^{3+}\left(\mathrm{SO}_{4}\right)_{2} \cdot 12 \mathrm{H}_{2} \mathrm{O}$ in which $\mathrm{X}$ site is occupied by $\mathrm{Na}, \mathrm{K}, \mathrm{NH}_{4}$, and Tl. The crystal structure of the mineral is given in Figure 3. Biagioni et al. [35] documented Tlbearing alum (K) from the Apuan Alps in Italy and argued that the substitution of $\mathrm{Al}^{3+}$ 
by $\mathrm{Fe}^{3+}$ and $\mathrm{K}^{+}$by both $\mathrm{NH}_{4}^{+}$and $\mathrm{Tl}^{+}$are responsible for the nonlinear variation of the unit-crystal parameter from Alum(K) to lanmuchangite.

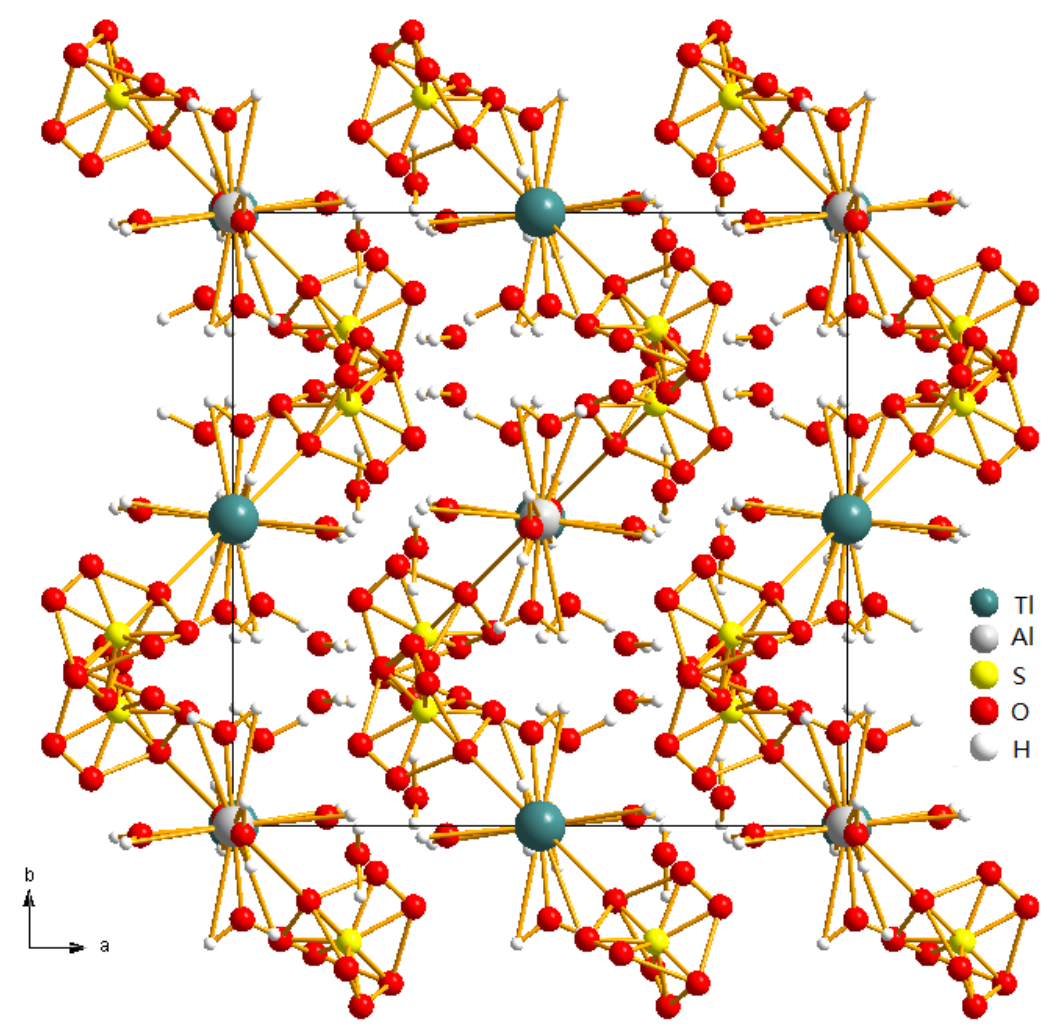

Figure 3. Crystal structure of Lanmuchangite.

Thallium voltaite $\left((\mathrm{K}, \mathrm{Tl}) \mathrm{Fe}^{2+}{ }_{5} \mathrm{Fe}^{3+}{ }_{3} \mathrm{Al}\left(\mathrm{SO}_{4}\right)_{12} \cdot 18 \mathrm{H}_{2} \mathrm{O}\right)$ is reported in the oxidized zone of thallium deposits (e.g., Tuscany of Italy), which was first named as a new $\mathrm{Tl}^{3+}-\mathrm{K}$ mineral monsmedite and was later discredited [35]. The study suggests that the unit-cell parameter ( $a=27.2587 \AA$ and $a=27.2635 \AA$ for Romania and Italy, respectively) of Tl voltaite is slightly larger than that of synthetic $\mathrm{K}_{2} \mathrm{Fe}^{2+}{ }_{5} \mathrm{Fe}^{3+}{ }_{3} \mathrm{Al}\left(\mathrm{SO}_{4}\right){ }_{12} \cdot 18 \mathrm{H}_{2} \mathrm{O}(a=27.234 \AA)[35,144]$. It is reported that $\mathrm{Tl}$ voltaite is chemically zoned with $\mathrm{Tl}$ more enriched in the rims $\left(\mathrm{Tl}_{2} \mathrm{O}\right.$ $3.30 \%)$ than in the core $\left(\mathrm{Tl}_{2} \mathrm{O} 2.88 \%\right)$ of the voltaite as revealed by electron microprobe analyses [35]. The $\mathrm{Tl}$ voltaite closely occurs with more than 15 secondary sulfate minerals. The K site replacement by $\mathrm{Tl}$ in the voltaite from Apuan Alps has been confirmed by quantitative EXAFS and single-crystal X-ray diffraction refinement [35].

Pyrite oxidation and subsequent $\mathrm{Tl}$ release and $\mathrm{K}$ substitution by $\mathrm{Tl}$ in various ratios in the secondary $\mathrm{K}$ sulfate are responsible for the formation of dorallcharite, lanmuchangite, voltaite, and other $\mathrm{K}$ sulfate minerals, as evidenced the elevated content of $\mathrm{Tl}$ in alum(-K) $\left(\mathrm{KAl}\left(\mathrm{SO}_{4}\right)_{2} \cdot 12 \mathrm{H}_{2} \mathrm{O}\right)$, goldichite $\left(\mathrm{KFe}^{3+}\left(\mathrm{SO}_{4}\right)_{2} \cdot 4\left(\mathrm{H}_{2} \mathrm{O}\right)\right)$, jarosite $\left(\mathrm{KFe}^{3+}\left(\mathrm{SO}_{4}\right)_{2} \cdot(\mathrm{OH})_{6}\right)$ and krausite $\left(\mathrm{KFe}^{3+}\left(\mathrm{SO}_{4}\right)_{2} \cdot\left(\mathrm{H}_{2} \mathrm{O}\right)\right)$ in Apuan Alps [69] and Lanmuchang [145]. It is expected that some $\mathrm{K}$ sulfate minerals from Apuan Alps, in which $\mathrm{Tl}$ contents have not been analyzed, such as giacovazzoite $\left(\mathrm{K}_{5} \mathrm{Fe}^{3+}{ }_{3} \mathrm{O}\left(\mathrm{SO}_{4}\right)_{6} \cdot 10 \mathrm{H}_{2} \mathrm{O}\right)$, Magnanelliite $\left(\mathrm{K}_{3} \mathrm{Fe}^{3+}{ }_{2}\left(\mathrm{SO}_{4}\right)_{4}(\mathrm{OH})\left(\mathrm{H}_{2} \mathrm{O}\right)_{2}\right)$, and scordariite $\left(\mathrm{K}_{8}\left(\mathrm{Fe}^{3+}{ }_{0.67} \square_{0.33}\right)\left[\mathrm{Fe}^{3+}{ }_{3} \mathrm{O}\left(\mathrm{SO}_{4}\right)_{6}\right]_{2} \cdot 14 \mathrm{H}_{2} \mathrm{O}\right)$, should contain high $\mathrm{Tl}$ concentrations.

\subsection{Secondary Iron Sulfate}

Secondary iron sulfates including ferrous sulfate melanterite $\left(\mathrm{Fe}^{2+}\left(\mathrm{SO}_{4}\right) \cdot\left(\mathrm{H}_{2} \mathrm{O}\right)_{7}\right)$ and halotrichite $\left(\mathrm{Fe}^{2+} \mathrm{Al}_{2}\left(\mathrm{SO}_{4}\right)_{4} \cdot 22 \mathrm{H}_{2} \mathrm{O}\right)$, mixing ferrous and ferric sulfate römerite $\left(\mathrm{Fe}^{2+} \mathrm{Fe}^{3+}{ }_{2}\left(\mathrm{SO}_{4}\right)_{4} \cdot 14 \mathrm{H}_{2} \mathrm{O}\right)$, and ferric sulfate fibroferrite $\left(\mathrm{Fe}^{3+}\left(\mathrm{SO}_{4}\right)(\mathrm{OH}) \cdot 5 \mathrm{H}_{2} \mathrm{O}\right)$ are found in the oxidized zone of thallium deposit $[68,69]$. Melanterite is the most common secondary sulfate mineral formed in the earliest period of pyrite oxidation [29]. Partial 
oxidation of ferrous iron in the solution under acid conditions leads to the formation of romerite and fibroferrite. Due to the significant ionic radius difference between iron and thallium, only a trace amount of $\mathrm{Tl}$ is incorporated into iron-sulfate minerals [69]. All reported four iron-sulfate minerals are more soluble than jarosite and schwertmannite $\left(\mathrm{Fe}_{8} \mathrm{O}_{8}(\mathrm{OH})_{6} \mathrm{SO}_{4} \cdot \mathrm{nH}_{2} \mathrm{O}\right)[29]$.

\subsection{Secondary Calcium, Magnesium, Aluminum Sulfate}

Gypsum $\left(\mathrm{CaSO}_{4} \cdot 2 \mathrm{H}_{2} \mathrm{O}\right)$, anhydrite $\left(\mathrm{CaSO}_{4}\right)$, alunogen $\left(\mathrm{Al}_{2}\left(\mathrm{SO}_{4}\right)_{3} \cdot 17\left(\mathrm{H}_{2} \mathrm{O}\right)\right)$, coquimbite $\left(\mathrm{AlFe}_{3}^{3+}\left(\mathrm{SO}_{4}\right)_{6}\left(\mathrm{H}_{2} \mathrm{O}\right) 12 \cdot 6\left(\mathrm{H}_{2} \mathrm{O}\right)\right)$, khademite $\left(\mathrm{Al}\left(\mathrm{SO}_{4}\right) \mathrm{F} \cdot 5\left(\mathrm{H}_{2} \mathrm{O}\right)\right)$, pickeringite $\left(\mathrm{MgAl}_{2}\left(\mathrm{SO}_{4}\right)_{4} \cdot 22 \mathrm{H}_{2} \mathrm{O}\right)$, and magnesiocopiapite $\left(\mathrm{MgFe}^{3+}{ }_{4}\left(\mathrm{SO}_{4}\right)_{6}(\mathrm{OH})_{2}\left(\mathrm{H}_{2} \mathrm{O}\right)_{14} \cdot 6 \mathrm{H}_{2} \mathrm{O}\right)$ are reported secondary calcium, aluminum, and magnesium sulfate in thallium deposit $[68,69]$. All these sulfate minerals have high solubility, especially in acid solutions [29]. Crystal chemical difference between $\mathrm{Tl}$ and $\mathrm{Ca}, \mathrm{Mg}$, and $\mathrm{Al}$ inhibits $\mathrm{Tl}$ from entering the crystal lattice of these minerals.

\section{Environmental Significance of the Secondary Sulfate Minerals}

Precipitation and dissolution of the secondary sulfate mineral in the alternating wetdry climate in mining areas can store or release acid and/or toxic elements. Owing to the varied $\mathrm{Tl}$ concentration, crystal structure and composition, and solubility, the secondary sulfate minerals play different roles in the environment.

\subsection{Tl Sulfate}

Natural Tl sulfate mineral lanmuchangite is readily soluble in water [68] and remains stable only in acidic conditions [16]; therefore, lanmuchangite serves as a transient Tl source and sink in the Tl-bearing mining environment. A high concentration of $\mathrm{Tl}$ appeared in rims of the voltaite at Alpuan mine, which suggests that $\mathrm{Tl}$ is enriched in the sulfide oxidation in K-poor environments [69]. Unfortunately, no literature is documented for Tl behavior during voltaite dissolution.

Tl-jarosite, which is transformed to dorallcharite when $\mathrm{Tl}$ completely substitutes $\mathrm{K}$ in the jarosite crystal lattice, represents common $\mathrm{Tl}$ sulfate in the $\mathrm{Tl}$ mining areas. In contrast to lanmuchangite, jarosite is relatively insoluble in water [67]. Moreover, jarosite and most other sulfate minerals are formed in acid conditions [146]. Therefore, Tl-jarosite plays a pivotal role in the storage of acid and $\mathrm{Tl}$ following sulfide weathering and oxidation and serves as a long-term sink for $\mathrm{Tl}$ and acid, notably in acid mine drainage and acid soil. Interestingly, the sites where these $\mathrm{Tl}$ sulfate minerals are documented, namely Allchar, Lanmuchang, and Tuscany, are Tl-rich deposits and notorious Tl-polluted areas [6]. Thus, occurrence of $\mathrm{Tl}$ sulfate minerals implies Tl-rich geological settings and abundant $\mathrm{Tl}$ release from oxidation of Tl-bearing sulfide minerals.

Thermodynamic modeling shows a wide stability field for dorallcharite [69]. Dorallcharite and Tl-jarosite are susceptible to significantly incongruent dissolution to release $\mathrm{Tl}$ and form iron hydroxides or schwertmannite under circumneutral $\mathrm{pH}$ conditions as described by the following reaction [147-149]:

$$
\left(\mathrm{Tl}_{\mathrm{x}}, \mathrm{K}_{1-\mathrm{x}}\right) \mathrm{Fe}_{3}\left(\mathrm{SO}_{4}\right)_{2}(\mathrm{OH})_{6}+2 \mathrm{H}_{2} \mathrm{O}=3 \mathrm{Fe}(\mathrm{OH})_{3}+\mathrm{xTl}^{+}+(1-\mathrm{x}) \mathrm{K}^{+}+2 \mathrm{SO}_{4}{ }^{2-}+3 \mathrm{H}^{+}
$$

The dissolution is also enhanced by microbial reduction of structural Fe and S. Dissimilatory iron-reducing bacteria (DIRB) (e.g., Shewanella putrefaciens CN32, Geobacter metalloproteins) have been proved using iron oxides as an electron acceptor for respiration. Jarosite enhanced reductive dissolution and iron oxides formation by Shewanella putrefaciens CN32, and Shewanella oneidensis MR-1 have been well recognized under anaerobic and neutral pH conditions $[69,150]$. Sulfate-reducing bacteria (SRB) can use sulfate as a terminal electron acceptor, and reductive-dissolution of jarosite by SRB has also been argued in anaerobic conditions [151-153]. Aqueous Tl data, adsorption experiments, and thermodynamic modeling demonstrate $\mathrm{Tl}$ did not have strong affinity for the iron oxides [147-149,154]. Taken together, 
Tl-jarosite and dorallcharite dissolution will increase $\mathrm{Tl}$ mobility and bioavailability driven by biotic and abiotic processes.

\subsection{Calcium, Magnesium, Alumina, and Iron Sulfate}

The pyrite's predominance in sulfides and Tl-hosted phases of $\mathrm{Tl}$ ore bodies, pyrite oxidation, and the subsequent sulfate mineral formation play a significant role in $\mathrm{Tl}$ release from primary Tl-hosted phases. It is commonly accepted that abiotic pyrite oxidation proceeds as the following simplified reactions [155]:

$$
\begin{gathered}
\mathrm{FeS}_{2}+7 / 2 \mathrm{O}_{2}+\mathrm{H}_{2} \mathrm{O} \rightarrow \mathrm{Fe}^{2+}+2 \mathrm{SO}_{4}{ }^{2-}+2 \mathrm{H}^{+} \\
\mathrm{Fe}^{2+}+1 / 4 \mathrm{O}_{2}+\mathrm{H}^{+} \rightarrow \mathrm{Fe}^{3+}+1 / 2 \mathrm{H}_{2} \mathrm{O} \\
\mathrm{Fe}^{3+}+3 \mathrm{H}_{2} \mathrm{O} \rightarrow \mathrm{Fe}(\mathrm{OH})_{3}+3 \mathrm{H}^{+} \\
\mathrm{FeS}_{2}+14 \mathrm{Fe}^{3+}+8 \mathrm{H}_{2} \mathrm{O} \rightarrow 15 \mathrm{Fe}^{2+}+2 \mathrm{SO}_{4}{ }^{2-}+16 \mathrm{H}^{+}
\end{gathered}
$$

Soluble minerals (e.g., gypsum, alum (without $\mathrm{K}$ ), melanterite, halotrichite, römerite, and fibroferrite) may precipitate at the surface of mineralized rocks during dry periods [156]. These sulfate minerals are highly impossible to act as a temporary or long-term storage for $\mathrm{Tl}$ for the crystal chemistry reason as evidenced by trace amounts of $\mathrm{Tl}$ in these minerals mentioned in Sections 3.2 and 3.3. Besides, we argued that redox cycling between ferrous and ferric iron in Equations (3) and (5) might impact the Tl release from Tl-bearing sulfide oxidation. It is well known that ferrous iron oxidizes to ferric iron in Equation (3) during pyrite oxidation and is a rate-limiting step [155]. Moreover, the ferrous iron that oxidizes to ferric iron is also $\mathrm{pH}$ dependent. Under the circumneutral $\mathrm{pH}$ conditions, the ferric iron tends to hydrolyze to ferrihydrite, which causes the removal of ferric iron from the aqueous system. Since the rate of pyrite oxidation involving $\mathrm{Fe}^{3+}$ is significantly higher than that of $\mathrm{O}_{2}$, as suggested by reaction Equation (2), the $\mathrm{O}_{2}$-dominated pyrite oxidation will proceed at a relatively lower rate. At the low $\mathrm{pH}$ conditions resulting from the secondary sulfate dissolution during the wet periods, ferric iron oxidizing pyrite in Equation (5) is preferred to Equation (4). Thus, Equations (3) and (5) construct a closed iron cycling to prompt the pyrite oxidation approach to a steady state.

The ferrous iron oxidation rate in Equation (3) becomes very slow at lower $\mathrm{pH}$ values, and dissolution and adding of ferric iron sulfate minerals (e.g., fibroferrite) may compensate for the lower rate. Despite the effectiveness of microbial catalysis for pyrite oxidation process, abiotic pyrite oxidation at depth is argued at the global scale owing to the pore limit for the access of bacteria [157]. Therefore, precipitation and dissolution of soluble iron-sulfate minerals probably sustains long-term pyrite oxidation and associated $\mathrm{Tl}$ release in areas impacted by $\mathrm{Tl}$ mining and processing.

\section{Conclusions}

$\mathrm{Tl}$ is a highly toxic heavy metal that is strictly regulated by many countries but has an irreplaceable role in several high-tech fields, and is mainly introduced into the environment unintentionally by the mining, mineral processing, and metallurgy related to Tl-(bearing) deposits. The numerous discoveries of new $\mathrm{Tl}$ minerals and Tl-bearing deposits in recent years suggest that the risk of $\mathrm{Tl}$ exposure is much higher than documented, and the potential $\mathrm{Tl}$ pollution associated with the mining activities has attracted considerable attention. Although up to $89 \mathrm{Tl}$ minerals have been reported, hydrothermal pyrite is the predominant Tl-bearing phase in most Tl-(bearing) deposits. Pyrite oxidation not only generates acid but also releases $\mathrm{Tl}$ into the environment. Thallium and other metal sulfate minerals formed during the dry season play varied roles in Tl mobility and scavenging due to different crystal chemistry signatures. Furthermore, secondary sulfate minerals dissolution and ferric iron adding can accelerate the pyrite oxidation and $\mathrm{Tl}$ release from pyrite and other Tl-bearing sulfides. 
More in-depth knowledge is needed about the behavior of Tl release during $\mathrm{Tl}$ sulfide minerals oxidation and constrained factors under different natural conditions. Besides, the roles that the secondary sulfate minerals play on $\mathrm{Tl}$ uptake by plants should be further investigated in future works. These efforts could enable us to control Tl pollution and reclaim Tl-polluted lands.

Author Contributions: F.Z. performed the thallium minerals compilation and wrote this paper; S.G. designed and supervised the project. All authors have read and agreed to the published version of the manuscript.

Funding: The research work is supported by the National Key Research and Development Program of China (No. 2018YFC1802601).

Acknowledgments: We would like to thank the editors and anonymous reviewers for their helpful comments which greatly improved the manuscript.

Conflicts of Interest: The authors declare no conflict of interest.

\section{References}

1. Li, J.; Zhu, R.; Huang, L.; Pan, J.; Guo, C.; Cao, Y. Tracking observation for chronic thallium poisoning in Huilong Valley of Xingren County, China. Occup. Health Inj. 1986, 1, 52-54. (In Chinese)

2. Viraraghavan, T.; Srinivasan, A. Thallium: Environmental Pollution and Health Effects. In Encyclopedia of Environmental Health; Nriagu, J.O., Ed.; Elsevier Inc.: Burlington, VT, USA, 2011; pp. 325-333.

3. Liu, J.; Wang, J.; Tsang, D.C.W.; Xiao, T.; Chen, Y.; Hou, L. Emerging thallium pollution in China and source tracing by thallium isotopes. Environ. Sci. Technol. 2018, 52, 11977-11979. [CrossRef]

4. Kazantzis, G. Thallium in the Environment and Health Effects. Environ. Geochem. Health 2000, 22, 275-280. [CrossRef]

5. Xiao, T.; Boyle, D.; Guha, J.; Rouleau, A.; Hong, Y.; Zheng, B. Groundwater-related thallium transfer processes and their impacts on the ecosystem: Southwest Guizhou Province, China. Appl. Geochem. 2003, 18, 675-691. [CrossRef]

6. Liu, J.; Luo, X.; Sun, Y.; Tsang, D.C.; Qi, J.; Zhang, W.; Li, N.; Yin, M.; Wang, J.; Lippold, H.; et al. Thallium pollution in China and removal technologies for waters: A review. Environ. Int. 2019, 126, 771-790. [CrossRef] [PubMed]

7. Wen, H.; Zhu, C.; Du, S.; Fan, Y.; Luo, C. Gallium (Ga), germanium (Ge), thallium (Tl) and cadmium (Cd) resources in China. Chin. Sci. Bull. 2020, 65, 3688-3699. (In Chinese with English abstract)

8. Ikramuddin, M.; Besse, L.; Nordstrom, P.M. Thallium in the Carlin-type gold deposits. Appl. Geochem. 1986, 1, 493-502. [CrossRef]

9. Janković, S. Sb-As-Tl mineral association in the Mediterranean region. Int. Geol. Rev. 1989, 31, 262-273. [CrossRef]

10. Hofstra, A.H. Characteristics and models for Carlin-type gold deposits. Rev. Econ. Geol. 2000, 13, 163-220.

11. Fan, Y.; Zhou, T.; Gabriel, V.; Hu, Q.; Yuan, F.; Zhang, X. Metallogenic regularities of thallium deposits. Geol. Sci. Technol. Inf. 2005, $24,55-60$.

12. Xiao, T.; Yang, F.; Li, S.; Zheng, B.; Ning, Z. Thallium pollution in China: A geo-environmental perspective. Sci. Total Environ. 2012, 421, 51-58. [CrossRef]

13. Jakubowska, M.; Pasieczna, A.; Zembrzuski, W.; Swit, Z.; Lukaszewski, Z. Thallium in fractions of soil formed on floodplain terraces. Chemosphere 2007, 66, 611-618. [CrossRef]

14. Karbowska, B.; Zembrzuski, W.; Jakubowska, M.; Wojtkowiak, T.; Pasieczna, A.; Lukaszewski, Z. Translocation and mobility of thallium from zinc-lead ores. J. Geochem. Explor. 2014, 143, 127-135. [CrossRef]

15. Xiong, Y.L. The aqueous geochemistry of thallium: Speciation and solubility of thallium in low temperature systems. Environ. Chem. 2009, 6, 441-451. [CrossRef]

16. Vaněk, A.; Komárek, M.; Chrastný, V.; Galušková, I.; Mihaljevič, M.; Šebek, O.; Drahota, P.; Tejnecký, V.; Vokurková, P. Effect of low-molecular-weight organic acids on the leaching of thallium and accompanying cations from soil-a model rhizosphere solution approach. J. Geochem. Explor. 2012, 112, 212-217. [CrossRef]

17. Zitko, V. Toxicity and pollution potential of thallium. Sci. Total Environ. 1975, 4, 185-192. [CrossRef]

18. Jonsson, E.; Wagner, T. Ore Mineralogy of the Skrikerum Cu-Ag-Tl-(Au) Selenide Deposit, SE Sweden: Preliminary Results. In Proceedings of the 25th Nordic Geological Winter Meeting, Reykjavík, Iceland, 6-9 January 2002; 98.

19. Zhang, Z.; Zhang, X.; Zhang, B. Elemental geochemistry and metallogenic model of Nanhua As-Tl deposit in Yunnan Province, China. Geochimica 1998, 27, 269-275. (In Chinese with English abstract)

20. Yang, C.; Chen, Y.; Peng, P.; Li, C.; Chang, X.; Xie, C. Distribution of natural and anthropogenic thallium in the soils in an industrial pyrite slag disposing area. Sci. Total Environ. 2005, 341, 159-172. [CrossRef] [PubMed]

21. Li, G. A study of ore compositions and thallium occurrence in a mercury-thallium deposit at Lanmuchang in Xingren County in southwestern Guizhou. Guizhou Geol. 1996, 13, 24-37. (In Chinese with English abstract)

22. Hu, R.; Peng, J.; Ma, D.; Su, W.; Shi, C.; Bi, X.; Tu, G. Epoch of large-scale low temperature mineralizations in southwestern Yangtze massif. Miner. Depos. 2007, 26, 583-596. (In Chinese with English abstract) 
23. Zhou, T.; Fan, Y.; Yuan, F.; Wu, M.; Hou, M.; Voicu, G.; Hu, Q.; Zhang, Q.; Yue, S. A preliminary geological and geochemical study of the Xiangquan thallium deposit, eastern China: The world's first thallium-only mine. Miner. Petrol. 2005, 85, $243-251$. [CrossRef]

24. George, L.L.; Biagioni, C.; D'Orazio, M.; Cook, N.J. Textural and trace element evolution of pyrite during greenschist facies metamorphic recrystallization in the southern Apuan Alps (Tuscany, Italy): Influence on the formation of Tl-rich sulfosalt melt. Ore Geol. Rev. 2018, 102, 59-105. [CrossRef]

25. Chang, X.; Chen, Y.; Liu, J.; Chen, N.W.Y.; Fu, S. Effect of thallium-bearing sulfide mineral utilization on environment in Yunfu of west Guangdong: Trace study of lead isotope. Acta Geosci. Sin. 2008, 29, 765-768. (In Chinese with English abstract)

26. Jiang, K.; Yan, Y.; Zhu, C.; Zhang, L. The research on distribution of thallium and cadmium in the Jinding lead-zinc Deposit, Yunnan Province. Bull. Miner. Petrol. Geochem. 2014, 33, 753-758, (in Chinese with English abstract).

27. Spinks, S.; Pearce, M.; Liu, W.; Kunzmann, M.; Ryan, C.; Moorhead, G.; Kirkham, R.; Blaikie, T.; Sheldon, H.; Schaubs, P.; et al. Carbonate replacement as the principal ore formation process in the Proterozoic McArthur River (HYC) sediment-hosted Zn-Pb Deposit, Australia. Econ. Geol. 2021, 116, 693-718. [CrossRef]

28. Dehnavi, A.; Mcfarlane, C.; Lentz, D.; Walker, J. Assessment of pyrite composition by LA-ICP-MS techniques from massive sulfide deposits of the Bathurst Mining Camp, Canada: From textural and chemical evolution to its application as a vectoring tool for the exploration of VMS deposits. Ore Geol. Rev. 2018, 92, 656-671. [CrossRef]

29. Jambor, J.L.; Nordstrom, D.K.; Alpers, C.N. Metal-sulfate salts from sulfide mineral oxidation. Rev. Mineral. Geochem. 2000, 40, 303-350. [CrossRef]

30. Muntean, J.L. The Carlin gold system: Applications to exploration in Nevada and beyond. Rev. Econ. Geol. 2018, $20,39-88$.

31. Chen, D. Discovery of rich-thallium ore body in paragenesis ore deposit of mercury and thallium and research of its mineralization mechanism. J. Guizhou Inst. Technol. 1989, 18, 1-19. (In Chinese with English abstract)

32. Hofstra, A.H.; Christensen, O.D. Comparison of Carlin-type Au deposits in the United States, China, and Indonesia-Implications for genetic models and exploration. US Geol. Surv. Open-File Report. 2002, 02-131, 64-94.

33. Nevolko, P.A.; Hnylko, O.M.; Mokrushnikov, V.P.; Gibsher, A.S.; Redin, Y.O.; Zhimulev, F.I.; Karavashkin, M.I. Geology and geochemistry of the Kadamzhai and Chauvai gold-antimony- mercury deposits: Implications for new province of Carlin-type gold deposits at the Southern Tien Shan (Kyrgyzstan). Ore Geol. Rev. 2019, 105, 551-571. [CrossRef]

34. Vikentyev, I.V.; Tyukova, E.E.; Vikent'Eva, O.V.; Chugaev, A.V.; Dubinina, E.O.; Prokofiev, V.Y.; Murzin, V.V. Vorontsovka Carlin-style gold deposit in the North Urals: Mineralogy, fluid inclusion and isotope data for genetic model. Chem. Geol. 2019, 508, 144-166. [CrossRef]

35. Biagioni, C.; D'Orazio, M.; Fulignati, P.; George, L.L.; Mauro, D.; Zaccarini, F. Sulfide melts in ore deposits from low-grade metamorphic settings: Insights from fluid and Tl-rich sulfosalt microinclusions from the Monte Arsiccio mine (Apuan Alps, Tuscany, Italy). Ore Geol. Rev. 2020, 123, 103589. [CrossRef]

36. Zen, X.; Wu, Y. Polygenetic mechanism for compound enriched Yunfu pyrite, Guangdong Province. Geotect. Metallogen. 1998, 22, 242-251.

37. Biagioni, C.; D’Orazio, M.; Vezzoni, S.; Dini, A.; Orlandi, P. Mobilization of Tl-Hg-As-Sb-(Ag,Cu)-Pb sulfosalt melts during low-grade metamorphism in the Alpi Apuane (Tuscany, Italy). Geology 2013, 41, 747-751. [CrossRef]

38. Hettmann, K.; Kreissig, K.; Rehkämper, M.; Wenzel, T.; Mertz-Kraus, R.; Markl, G. Thallium geochemistry in the metamorphic Lengenbach sulfide deposit, Switzerland: Thallium-isotope fractionation in a sulfide melt. Am. Mineral. 2014, 99, 793-803. [CrossRef]

39. Wang, C.; Yang, L.; Bagas, L.; Evans, N.J.; Chen, J.; Du, B. Mineralization processes at the giant Jinding Zn-Pb deposit, Lanping Basin, Sanjiang Tethys Orogen: Evidence from in situ trace element analysis of pyrite and marcasite. Geol. J. 2018, 53, 1279-1294 [CrossRef]

40. Wu, M. Study of geologic characteristics of the Xiangquan thallium deposit, Anhui Province. J. Hefei Univ. Technol. 2006, 29, 1571-1576.

41. Muntean, J.; Cline, J.; Simon, A.; Longo, A. Magmatic-hydrothermal origin of Nevada's Carlin-type gold deposits. Nat. Geosci. 2011, 4, 122-127. [CrossRef]

42. Su, W.; Dong, W.; Zhang, X.; Shen, N.; Hu, R.; Hofstra, A.; Cheng, L.; Xia, Y.; Yang, K. Carlin-type gold deposits in the Dian-Qian-Gui “Golden Triangle” of Southwest China. Econ. Geol. 2018, 20, 157-185.

43. Xiong, Y.L. Hydrothermal thallium mineralization up to $300^{\circ} \mathrm{C}$ : A thermodynamic approach. Ore Geol. Rev. 2007, 32, 291-313. [CrossRef]

44. Sobott, R.; Klaes, R.; Moh, G. Thallium-containing mineral systems. Part I: Natural assemblages of Tl-sulfosalts and related laboratory experiments. Chen. Erde. 1987, 47, 195-218.

45. Chen, D.; Ren, D.; Hua, W.; Zou, Z.; Yun, Q. Where is the second thallium ore deposit of Lanmuchang type?-the discovery of Yangjiawan thallium prospect and its prospecting potentiality. J. Guizhou Inst. Technol. 1989, 27, 18-26. (In Chinese with English abstract)

46. Palinkaš, S.; Hofstra, A.; Percival, T.; Šoštaric, S.; Palinkaš, L.; Bermanec, V.; Pecskay, Z.; Boev, B. Comparison of the Allchar Au-As-Sb-Tl Deposit, Republic of Macedonia, with Carlin-type gold deposits. Rev. Econ. Geol. 2018, $20,335-363$.

47. Rader, S.T.; Mazdab, F.K.; Barton, M.D. Mineralogical thallium geochemistry and isotope variations from igneous, metamorphic, and metasomatic systems. Geochim. Cosmochim. Acta 2018, 243, 42-65. [CrossRef] 
48. Heinrichs, H.; Schulz-Dobrick, B.; Wedepohl, K. Terrestrial geochemistry of Cd, Bi, Tl, Pb, Zn and Rb. Geochim. Cosmochim. Acta 1980, 44, 1519-1533. [CrossRef]

49. Radtke, A.S.; Dicksonc, F.W. Carlinite, $\mathrm{Tl}_{2} \mathrm{~S}$, a new mineral from Nevada. Am. Mineral. 1975, 60, 559-565.

50. Herrmann, J.; Voegelin, A.; Palatinus, L.; Mangold, S.; Majzlan, J. Secondary Fe-As-Tl mineralization in soils near Buus in the Swiss Jura Mountains. Eur. J. Mineral. 2018, 30, 887-898. [CrossRef]

51. Nowacki, W.; Edenharter, A.; Engel, P.; Gostojić, M.; Nagl, A. On the Crystal Chemistry of Some Thallium Sulphides and Sulfosalts. In Ore Genesis-The State of Art; Amstutz, G.C., El Goresdy, A., Frenzel, G., Kluth, C., Moh, G., Wauschkuhn, A., Zimmermann, R.A., Eds.; Springer: Berlin/Heidelberg, Germany, 1982; pp. 689-704.

52. Zemann, J. Thallium in Mineralogie und Geochemie. Mitteilungen der Österreich. Miner. Gesselschaft. 1993, 138, 75-91.

53. Gržetić, I.; Balić-Žunić, T. The photoelectron spectra of some Tl-Sb sulphosalts. Phys. Chem. Miner. 1993, 20, 285-296. [CrossRef]

54. Makovicky, E. Modular crystal chemistry of thallium sulfosalts. Minerals 2018, 8, 478. [CrossRef]

55. Raber, T.; Roth, P. The Lengenbach quarry in Switzerland: Classic locality for rare thallium sulfosalts. Minerals 2018, 8, 409. [CrossRef]

56. Hofmann, B.A.; Knill, M.D. Geochemistry and genesis of the Lengenbach Pb-Zn-As-Tl-Ba-mineralisation, Binn Valley, Switzerland. Miner. Deposita 1996, 31, 319-339. [CrossRef]

57. Jovanovski, G.; Boev, B.; Makreski, P.; Stafilov, T.; Boev, I. Intriguing minerals: Lorandite, TlAsS 2 , a geochemical detector of solar neutrinos. ChemTexts 2019, 5, 1-5. [CrossRef]

58. Xie, G.; Mao, J.; Han, Y.; Jian, W.; Han, J. Discovery of lorandite TIAsS2 at the distal Au-Tl deposit in a skarn system, Fengshan Area, Middle Lower Yangtze River, Eastern China. Acta Geol. Sinica 2017, 91, 1493-1494. (In English) [CrossRef]

59. Welch, M.D.; Still, J.W.; Rice, C.M.; Stanley, C.J. A new telluride topology: The crystal structure of honeaite $\mathrm{Au}_{3} \mathrm{TlTe}_{2}$. Mineral. Mag. 2017, 81, 611-618. [CrossRef]

60. Rice, C.M.; Welch, M.D.; Still, J.W.; Criddle, A.J.; Stanley, C.J. Honeaite, a new gold-thallium-telluride from the Eastern Goldfields, Yilgarn Craton, Western Australia. Eur. J. Mineral. 2016, 28, 979-990. [CrossRef]

61. Okrugin, V.; Favero, M.; Liu, A.; Etschmann, B.; Plutachina, E.; Mills, S.; Brugger, J. Smoking gun for thallium geochemistry in volcanic arcs: Nataliyamalikite, TlI, a new thallium mineral from an active fumarole at Avacha Volcano, Kamchatka Peninsula, Russia. Am. Mineral. 2017, 102, 1736-1746. [CrossRef]

62. Campostrini, I.; Demartin, F.; Gramaccioli, C.M.; Orlandi, P. Hephaistosite. $\mathrm{TlPb}_{2} \mathrm{Cl}_{5}$, a new thallium mineral species from La Fossa crater, Vulcano, Aeolian Islands, Italy. Can. Mineral. 2008, 46, 701-708. [CrossRef]

63. Pekov, I.V.; Agakhanov, A.A.; Zubkova, N.V.; Koshlyakova, N.N.; Shchipalkina, N.V.; Sandalov, F.D.; Yapaskurt, V.O.; Turchkova, A.G.; Sidorov, E.G. Oxidizing-type fumaroles of the Tolbachik Volcano, a mineralogical and geochemical unique. Russ. Geol. Geophys. 2020, 61, 675-688. [CrossRef]

64. Voegelin, A.; Pfenninger, N.; Petrikis, J.; Majzlan, J.; Plötze, M.; Senn, A.C.; Göttlicher, J. Thallium speciation and extractability in a thallium-and arsenic-rich soil developed from mineralized carbonate rock. Environ. Sci. Technol. 2015, 49, 5390-5398. [CrossRef] [PubMed]

65. Cruz-Hernández, Y.; Villalobos, M.; Marcus, M.A.; Pi-Puig, T.; Zanella, R.; Martínez-Villegas, N. Tl(I) sorption behavior on birnessite and its implications for mineral structural changes. Geochim. Cosmochim. Acta 2019, 248, 356-369. [CrossRef]

66. Barkov, A.Y.; Shvedov, G.I.; Polonyankin, A.A.; Martin, R.F.; O’Driscoll, B. New and unusual Pd-Tl-bearing mineralization in the Anomal'nyi deposit, Kondyor concentrically zoned complex, northern Khabarovskiy kray, Russia. Mineral. Mag. 2017, 81, 679-688. [CrossRef]

67. Hammarstrom, J.M.; Seal II, R.R.; Meier, A.L.; Kornfeld, J.M. Secondary sulfate minerals associated with acid drainage in the eastern US: Recycling of metals and acidity in surficial environments. Chem. Geol. 2005, 215, 407-431. [CrossRef]

68. Chen, D.; Wang, G.; Zou, Z.; Chen, Y.M. A new mineral-Lanmuchangite. Acta Mineral. Sinica. 2001, 21, 271-277. (In Chinese with English abstract)

69. D'Orazio, M.; Mauro, D.; Valerio, M.; Biagioni, C. Secondary sulfates from the Monte Arsiccio Mine (Apuan Alps, Tuscany, Italy): Trace-element budget and role in the formation of acid mine drainage. Minerals 2021, 11, 206. [CrossRef]

70. Bermanec, V.; Palinkaš, L.A.; Fiket, Ž.; Hrenović, J.; Plenković-Moraj, A.; Kniewald, G.; Boev, B. Interaction of acid mine drainage with biota in the Allchar Carlin-type As-Tl-Sb-Au deposit, Macedonia. J. Geochem. Explor. 2018, 194, 104-119. [CrossRef]

71. Topa, D.; Makovicky, E. Argentobaumhauerite: Name, chemistry, crystal structure, comparison with baumhauerite, and position in the Lengenbach mineralization sequence. Mineral. Mag. 2016, 80, 819-840. [CrossRef]

72. Graeser, S.; Edenharter, A. Jentschite (TlPbAs $\left.{ }_{2} \mathrm{SbS}_{6}\right)$-a new sulphosalt mineral from Lengenbach, Binntal (Switzerland). Mineral. Mag. 1992, 72, 293-305.

73. Biagioni, C.; Bonaccorsi, E.; Moëlo, Y.; Orlandi, P.; Bindi, L.; D’Drazio, M.; Vezzoni, S. Mercury-arsenic sulfosalts from the Apuan Alps (Tuscany, Italy). II. Arsiccioite, $\mathrm{AgHg}_{2} \mathrm{TlAs}_{2} \mathrm{~S}_{6}$, a new mineral from the Monte Arsiccio mine: Occurrence, crystal structure and crystal chemistry of the routhierite isotypic series. Mineral. Mag. 2014, 78, 101-111. [CrossRef]

74. Pekov, I.V.; Zubkova, N.V.; Belakovskiy, D.I.; Yapaskurt, V.O.; Vigasina, M.F.; Lykova, I.S.; Sidorov, E.G.; Pushcharovsky, D.Y. Chrysothallite $\mathrm{K}_{6} \mathrm{Cu}_{6} \mathrm{Tl}^{3+} \mathrm{Cl}_{17}(\mathrm{OH})_{4} \cdot \mathrm{H}_{2} \mathrm{O}$, a new mineral species from the Tolbachik volcano, Kamchatka, Russia. Mineral. Mag. 2015, 79, 365-376. [CrossRef]

75. Miyawaki, R.; Hatert, F.; Pasero, M.; Mills, S.J. IMA Commission on New Minerals, Nomenclature and Classification (CNMNC) Newsletter 57. Eur. J. Mineral. 2020, 32, 498. [CrossRef] 
76. Siidra, O.I.; Vergasova, L.P.; Kretser, Y.L.; Polekhovsky, Y.S.; Filatov, S.K.; Krivovichev, S.V. Unique thallium mineralization in the fumaroles of Tolbachik volcano, Kamchatka Peninsula, Russia. II. Karpovite, $\mathrm{Tl}_{2} \mathrm{VO}\left(\mathrm{SO}_{4}\right) 2\left(\mathrm{H}_{2} \mathrm{O}\right)$. Mineral. Mag. 2014, 78, 1699-1709. [CrossRef]

77. Radtke, A.S.; Dickson, F.W.; Slack, J.F. Occurrence and formation of avicennite, $\mathrm{Tl}_{2} \mathrm{O}_{3}$, as a secondary mineral at the Carlin gold deposit, Nevada. Res. U.S. Geol. Surv. 1978, 6, 241-246.

78. Pašava, J.; Pertlik, F.; Stumpfl, E.F.; Zemann, J. Bernardite, a new thallium arsenic sulphosalt from Allchar, Macedonia, with a determination of the crystal structure. Mineral. Mag. 1989, 53, 531-538. [CrossRef]

79. Bindi, L.; Moëlo, Y. Biagioniite, $\mathrm{Tl}_{2} \mathrm{SbS}_{2}$, from the Hemlo gold deposit, Marathon, Ontario, Canada: Occurrence and crystal structure. Mineral. Mag. 2015, 79, 1089-1098. [CrossRef]

80. Radtke, A.S.; Taylor, C.M.; Erd, R.C.; Dickson, F. Occurrence of lorandite, $\mathrm{TlAsS}_{2}$, at the Carlin gold deposit, Nevada. Econ. Geol. 1974, 69, 121-123. [CrossRef]

81. Orlandi, P.; Biagioni, C.; Bonaccorsi, E.; Moëlo, Y.; Paar, W.H. Lead-antomony sulfosalts from Tuscany (Italy). XII. Boscardinite, $\mathrm{TlPb}_{4}\left(\mathrm{Sb}_{7} \mathrm{As}_{2}\right)_{9} \mathrm{~S}_{18}$, a new species from Monte Arsiccio mine: Occurrence and crystal structure. Can. Mineral. 2012, 50, 235-251. [CrossRef]

82. Siidra, O.I.; Vergasova, L.P.; Krivovichev, S.V.; Kretser, Y.L.; Zaitsev, A.N.; Filatov, S.K. Unique thallium mineralization in the fumaroles of Tolbachik volcano, Kamchatka Peninsula, Russia. I. Markhininite, TlBi(SO $\left.)_{4}\right)_{2}$. Mineral. Mag. 2014, 78, 1687-1698. [CrossRef]

83. Makovicky, E.; Johan, Z.; Karup-Møeller, S. New data on bukovite, thalcusite, chalcothallite and rohaite. Neues Jahrb. Mineral. Abh. 1980, 138, 122-146.

84. Biagioni, C.; Moëlo, Y.; Perchiazzi, N.; Demitri, N.; Zaccarini, F. Parapierrotite from the Monte Arsiccio mine (Apuan Alps, Tuscany, Italy): Occurrence and new data on its crystal-chemistry. Eur. J. Mineral. 2019, 31, 1055-1065. [CrossRef]

85. Bonaccorsi, E.; Biagioni, C.; Moëlo, Y.; Orlandi, P. Chabournéite from Monte Arsiccio Mine (Apuan Alps, Tuscany, Italy): Occurrence and Crystal Structure. In Proceedings of the 20th General Meeting of the IMA (IMA2010), Budapest, Hungary, 21-27 August 2010.

86. Artioli, G.; Kvick, A. Synchrotron X-ray Rietveld study of perlialite, the natural counterpart of synthetic zeolite-L, Sample: Data collected with synchrotron radiation. Eur. J. Mineral. 1990, 2, 749-759. [CrossRef]

87. Bindi, L.; Nestola, F.; Makovicky, E.; Guastoni, A.; De Battisti, L. Tl-bearing sulfosalt from the Lengenbach quarry, Binn Valley, Switzerland: Philrothite, TlAs ${ }_{3} \mathrm{~S}_{5}$. Mineral. Mag. 2014, 78, 1-9. [CrossRef]

88. Radtke, A.S.; Dickson, F.W.; Slack, J.F.; Brown, K.L. Christite, a new thallium mineral from the Carlin gold deposit, Nevada. Am. Mineral. 1977, 62, 421-425.

89. Balić-Žunić, T.; Karanovic, L.; Poleti, D. Crystal structure of picotpaulite, $\mathrm{TlFe}_{2} \mathrm{~S}_{3}$ from Allchar, FYR Macedonia. Acta Chim. Slov. 2008, 55, 801-809.

90. Engel, P.; Gostojić, M.; Nowacki, W. The crystal structure of pierrotite, $\mathrm{Tl}_{2}(\mathrm{Sb}, \mathrm{As})_{10} \mathrm{~S}_{16}$. Z. Krist.-Cryst. Mater. 1983, 165, $209-215$.

91. Harris, D.C.; Roberts, A.C.; Laflamme, J.H.G.; Stanley, C.J. Criddleite, $\mathrm{TlAg}_{2} \mathrm{Au}_{3} \mathrm{Sb}_{10} \mathrm{~S}_{10}$, a new gold-bearing mineral from Hemlo, Ontario, Canada. Mineral. Mag. 1988, 52, 691-697. [CrossRef]

92. Miyawaki, R.; Hatert, F.; Pasero, M.; Mills, S.J. IMA Commission on New Minerals, Nomenclature and Classification (CNMNC) Newsletter 55. Mineral. Mag. 2020, 84, 486. [CrossRef]

93. Palache, C.; Berman, H.; Frondel, C. The System of Mineralogy, Volume I: Elements, Sulfides, Sulfosalts, Oxides, 7th ed.; John Wiley \& Sons: Hoboken, NJ, USA, 1944; Volume 183, pp. 484-485.

94. Orlandi, P.; Biagioni, C.; Moëlo, Y.; Bonaccorsi, E.; Paar, W.H. Lead-antimony sulfosalts from Tuscany (Italy). XIII. Protochabournéite, $\sim \mathrm{Tl}_{2} \mathrm{~Pb}\left(\mathrm{Sb}_{9-8} \mathrm{As}_{1-2}\right)_{\sum 10} \mathrm{~S}_{17}$, from the Monte Arsiccio mine: Occurrence, crystal structure and relationship with chabournéite. Can. Mineral. 2013, 51, 475-494. [CrossRef]

95. Hålenius, U.; Ålinder, C. Occurrence and formation of cuprostibite in a Zn-Pb-Ag mineralized siliceous dolomite at Långsjön, central Sweden. Neues Jahrb. Mineral. Monatsh. 1982, 5, 201-215.

96. Bindi, L.; Nestola, F.; Guastoni, A.; Peruzzo, L.; Ecker, M.; Carampin, R. Raberite, $\mathrm{Tl}_{5} \mathrm{Ag}_{4} \mathrm{As}_{6} \mathrm{SbS}_{15}$, a new Tl-bearing sulfosalt from Lengenbach quarry, Binn valley, Switzerland: Description and crystal structure. Mineral. Mag. 2012, 76, 1153-1163. [CrossRef]

97. Nestola, F.; Guastoni, L.; Bindi, L.; Secco, L. Dalnegroite, $\mathrm{Tl}_{5-\mathrm{x}} \mathrm{Pb}_{2 \mathrm{x}}(\mathrm{As}, \mathrm{Sb})_{21-\mathrm{x}} \mathrm{S}_{34}$, a new thallium sulphosalt from Lengenbach quarry, Binntal, Switzerland. Mineral. Mag. 2009, 73, 1027-1032. [CrossRef]

98. Laurent, Y.; Picot, P.; Pierrot, R.; Ivanov, T. La Raguinite, $\mathrm{TlFeS}_{2}$, une nouvelle espèce minérale et Ie problème de l'allcharite. Bull. Minéralogie. 1969, 92, 38-48, (In French with English abstract).

99. Hålenius, U.; Hatert, F. IMA Commission on New Minerals, Nomenclature and Classification (CNMNC) Newsletter 40. Eur. J. Mineral. 2017, 29, 1084.

100. Bindi, L.; Biagioni, C.; Raber, T.; Roth, P.; Nestola, F. Ralphcannonite, $\mathrm{AgZn}_{2} \mathrm{TlAs}_{2} \mathrm{~S}_{6}$, a new mineral of the routhierite isotypic series from Lengenbach, Binn Valley, Switzerland. Mineral. Mag. 2015, 79, 1089-1098. [CrossRef]

101. Balic-Žunic, T.; Moëlo, Y.; Loncar, Z.; Micheelsen, H. Dorallcharite, $\mathrm{Tl}_{0.8} \mathrm{~K}_{0.2} \mathrm{Fe}_{3}\left(\mathrm{SO}_{4}\right)_{2}(\mathrm{OH})_{6}$, a new member of the jarosite-alunite family. Eur. J. Mineral. 1994, 6, 255-263.

102. Berlepsch, P.; Armbruster, T.; Topa, D. Structural and chemical variations in rathite, $\mathrm{Pb}_{8} \mathrm{~Pb}_{4-\mathrm{x}}\left(\mathrm{Tl}_{2} \mathrm{As}_{2}\right)_{\mathrm{x}}\left(\mathrm{Ag}_{2} \mathrm{As}_{2}\right) \mathrm{As}_{16} \mathrm{~S}_{40}: \mathrm{Modula}$ tions of a parent structure. Z. Krist.-Cryst. Mater. 2002, 217, 580-590. [CrossRef] 
103. Miyawak, R.; Hatert, F.; Pasero, M.; Mills, S.J. IMA Commission on New Minerals, Nomenclature and Classification (CNMNC) Newsletter 52. Eur. J. Mineral. 2020, 32, 3-4.

104. Basu, K.; Bortinikov, N.S.; Mookherjee, A.; Mozgova, N.N.; Tsepin, A.I.; Vyal'sov, L.N. Rare minerals from Rajpura-Dariba, Rajasthan, India. IV: A new Pb-Ag-Tl-Sb sulfosalt, rayite. Neues Jahrb. Mineral. Monatsh. 1983, 7, $296-304$.

105. Topa, D.; Kolitsch, U.; Makovicky, E.; Stanley, C. Écrinsite, $\mathrm{AgTl}_{3} \mathrm{~Pb}_{4} \mathrm{As}_{11} \mathrm{Sb}_{9} \mathrm{~S}_{36}$, a new thallium-rich homeotype of baumhauerite from the Jas Roux sulphosalt deposit, Parc National des Écrins, Hautes-Alpes, France. Eur. J. Mineral. 2017, 29, 689-700. [CrossRef]

106. Balić-Žunić, T.; Šcavničar, S.; Engel, P. The crystal structure of rebulite, $\mathrm{Tl}_{5} \mathrm{Sb}_{5} \mathrm{As}_{8} \mathrm{~S}_{22}$. Z. Krist.-Cryst. Mater. 1982, 160, 109-126.

107. Graeser, S.; Schwander, H. Edenharterite $\left(\mathrm{TlPbAs}_{3} \mathrm{~S}_{6}\right)$ : A new mineral from Lengenbach, Binntal (Switzerland). Eur. J. Mineral. 1992, 4, 1265-1270. [CrossRef]

108. Meisser, N.; Roth, P.; Nestola, F.; Biagioni, C.; Bindi, L.; Robyr, M. Richardsollyite, TlPbAsS 3 , a new sulfosalt from the Lengenbach quarry, Binn Valley, Switzerland. Eur. J. Mineral. 2017, 29, 679-688. [CrossRef]

109. Dickson, F.W.; Radtke, A.S.; Peterson, J.A. Ellisite, $\mathrm{Tl}_{3} \mathrm{AsS}_{3}$, a new mineral from the Carlin gold deposit, Nevada, and associated sulfide and sulfosalt minerals. Am. Mineral. 1979, 64, 701-770.

110. Graeser, S.; Schwaner, H.; Wulf, R.; Edenharter, A. Erniggliite $\left(\mathrm{Tl}_{2} \mathrm{SnAs}_{2} \mathrm{~S}_{6}\right)$, a new mineral from Lengenbach, Binntal (Switzerland): Description and crystal stucture determination based on data from synchrotron radiation. Schweiz. Mineral. Petrogr. Mitteilungen. $1992,5,259-260$.

111. Biagioni, C.; Bonaccorsi, E.; Moëlo, Y.; Orlandi, P. Mercury-arsenic sulfosalts from Apuan Alps (Tuscany, Italy). I. Routhierite, $\left(\mathrm{Cu}_{0.8} \mathrm{Ag}_{0.2}\right) \mathrm{Hg}_{2} \mathrm{Tl}\left(\mathrm{As}_{1.4} \mathrm{Sb}_{0.6}\right)_{\sum=2} \mathrm{~S}_{6}$, from Monte Arsiccio mine: Occurrenceand crystal structure. Eur. J. Mineral. 2014, 26, 163-170. [CrossRef]

112. Topa, D.; Makovicky, E.; Stöger, B.; Stanley, C. Heptasartorite, $\mathrm{Tl}_{7} \mathrm{~Pb}_{22} \mathrm{As}_{55} \mathrm{~S}_{108}$, enneasartorite, $\mathrm{Tl}_{6} \mathrm{~Pb}_{32} \mathrm{As}_{70} \mathrm{~S}_{140}$ and hendekasartorite, $\mathrm{Tl}_{2} \mathrm{~Pb}_{48} \mathrm{As}_{82} \mathrm{~S}_{172}$, three members of the anion-omission series of 'sartorites' from the Lengenbach quarry at Binntal, Wallis, Switzerland. Eur. J. Mineral. 2017, 29, 701-712. [CrossRef]

113. Johan, Z.; Kvacek, M.; Picot, P. La sabatierite, un nouveau seléniure de cuivre et de thalliumJ. Bull. Mineral. 1978, 101, 557-560.

114. Siidra, O.I.; Vergasova, L.P.; Kretser, Y.L.; Polekhovsky, Y.S.; Filatov, S.K.; Krivovichev, S.V. Unique thallium mineralization in the fumaroles of Tolbachik volcano, Kamchatka Peninsula, Russia. III. Evdokimovite, $\mathrm{Tl}_{4}(\mathrm{VO})_{3}\left(\mathrm{SO}_{4}\right)_{5}\left(\mathrm{H}_{2} \mathrm{O}\right)_{5}$. Mineral. Mag. 2014, 78, 1711-1724. [CrossRef]

115. Turchkova, A.G.; Pekov, I.V.; Yapaskurt, V.O.; Sidorov, E.G.; Britvin, S.N. Manganese mineralization in fumarole deposits at the Tolbachik volcano (Kamchatka, Russia). IX Intern. Sympos. Miner. Divers. Res. Preserv. Sofia 2017, 9.

116. Wilson, J.R.; Sen Gupta, P.K.; Robinson, P.D.; Criddle, A.J. Fangite, $\mathrm{Tl}_{3} \mathrm{AsS}_{4}$, a new thallium arsenic sulfosalt from the Mercur Au deposit, Utah, and revised optical data for gillulyite. Am. Mineral. 1993, 78, 1096-1103.

117. Graeser, S.; Berlepsch, P.; Makovvicky, E.; Balić-Žunić, T. Sicherite, $\mathrm{TlAg}_{2}(\mathrm{As}, \mathrm{Sb})_{3} \mathrm{~S}_{6}$, a new sulfosalt mineral from Lengenbach (Binntal, Switzerland): Description and structure determination. Mineral. Mag. 2001, 86, 1087-1093. [CrossRef]

118. Biagioni, C.; Bindi, L.; Nestola, F.; Cannon, R.; Roth, P.; Raber, T. Ferrostalderite, $\mathrm{CuFe}_{2} \mathrm{TlAs}_{2} \mathrm{~S}_{6}$, a new mineral from Lengenbach, Switzerland: Occurrence, crystal structure, and emphasis on the role of iron in sulfosalts. Mineral. Mag. 2014, 80, 175-186. [CrossRef]

119. Engel, P.; Nowacki, W. The crystal structure of simonite, $\mathrm{TIHgAs}_{3} \mathrm{~S}_{6}$. Z. Krist.-Cryst. Mater. 1982, 161, $159-166$.

120. Kasatkin, A.; Nestola, F.; Agakhanov, A.A.; Škoda, R.; Karpenko, V.Y.; Tsyganko, M.; Plášil, J. Vorontsovite, $\left(\mathrm{Hg}_{5} \mathrm{Cu}\right) \mathrm{S}_{6} \mathrm{TlAs}_{4} \mathrm{~S}_{12}$, and Ferrovorontsovite, $\left(\mathrm{Fe}_{5} \mathrm{Cu}\right) \mathrm{S}_{6} \mathrm{TlAs}_{4} \mathrm{~S}_{12}$ : The Tl- and Tl-Fe-analogues of galkhaite from the Vorontsovskoe Gold Deposit, Northern Urals, Russia. Minerals 2018, 8, 185. [CrossRef]

121. Willams, P.A.; Hatert, F.; Pasero, M.; Mills, S.J. IMA Commission on New Minerals, Nomenclature and Classification (CNMNC) Newsletter 20. Mineral. Mag. 2014, 78, 553-557.

122. Pekov, I.V.; Zubkova, N.V.; Yapaskurt, V.O.; Britvin, S.N.; Vigasina, M.F.; Sidorov, E.G.; Pushcharovsky, D.Y. New zinc and potassium chlorides from fumaroles of the Tolbachik volcano, Kamchatka, Russia: Mineral data and crystal chemistry. II. Flinteite, $\mathrm{K}_{2} \mathrm{ZnCl}_{4}$. Eur. J. Mineral. 2015, 27, 581-588. [CrossRef]

123. Graeser, S.; Schwander, H.; Wulf, R. Stalderite $\mathrm{TlCu}(\mathrm{Zn}, \mathrm{Fe}, \mathrm{Hg})_{2} \mathrm{As}_{2} \mathrm{~S}_{6}-\mathrm{A}$ new mineral related to routhierite: Description and crystal structure determination. Schweiz. Mineral. Petrogr. Mitt. 1995, 75, 337-345.

124. Graeser, S.; Topa, D.; Balić-Žunić, T.; Makovicky, E. Gabrielite, $\mathrm{Tl}_{2} \mathrm{AgCu}_{2} \mathrm{As}_{3} \mathrm{~S}_{7}$, a new species of thallium sulfosalt from Lengenbach, Binntal, Switzerland. Can. Mineral. 2006, 44, 135-140. [CrossRef]

125. Demartin, F.; Gramaccioli, C.M.; Campostrini, I. Steropesite, $\mathrm{Tl}_{3} \mathrm{BiCl}_{6}$, a new thallium bismuth chloride from La Fossa crater, Vulcano, Aeolian islands, Italy. Can. Mineral. 2009, 47, 373-380. [CrossRef]

126. Kasatkin, A.V.; Makovicky, E.; Plášil, J.; Škoda, R.; Chukanov, N.V.; Stepanov, S.Y.; Agakhanov, A.A.; Nestola, F. Gladkovskyite, $\mathrm{MnTlAs}_{3} \mathrm{~S}_{6}$, a new thallium sulfosalt from the Vorontsovskoe gold deposit, Northern Urals, Russia. J. Geosci. 2019, 64, 207-218. [CrossRef]

127. Rudashevskiy, N.S. Thalfenisite, the thallium analog of djerfisherite. Int. Geol. Rev. 1982, 24, 116-122. [CrossRef]

128. Miyawaki, R.; Hatert, F.; Pasero, M.; Mills, S.J. IMA Commission on New Minerals, Nomenclature and Classification (CNMNC) Newsletter 56. Mineral. Mag. 2020, 84, 623. [CrossRef]

129. Marumo, F.; Nowacki, W. The crystal structure of hatchite, PbTlAgAs $\mathrm{S}_{5}$. Z. Krist.-Cryst. Mater. 1967, 125, $249-265$.

130. Bindi, L.; Roberts, A.C. Thunderbayite, $\mathrm{TlAg}_{3} \mathrm{Au}_{3} \mathrm{Sb}_{7} \mathrm{~S}_{6}$, a new gold-bearing mineral from the Hemlo gold deposit, Marathon, Ontario, Canada. Mineral. Mag. 2020, 84, 805-812. [CrossRef] 
131. Kasatkin, A.V.; Makovicky, E.; Plášil, J.; Škoda, R.; Agakhanov, A.A.; Karpenko, V.Y.; Nestola, F. Tsygankoite, $\mathrm{Mn}_{8} \mathrm{Tl}_{8} \mathrm{Hg}_{2}$ $\left(\mathrm{Sb}_{21} \mathrm{~Pb}_{2} \mathrm{Tl}\right)_{\Sigma 24} \mathrm{~S}_{48}$, a New Sulfosalt from the Vorontsovskoe Gold Deposit, Northern Urals, Russia. Minerals 2018, 8, 218. [CrossRef]

132. Makovicky, E.; Topa, D. Twinnite, $\mathrm{Pb}_{0.8} \mathrm{Tl}_{0.1} \mathrm{Sb}_{1.3} \mathrm{As}_{0.8} \mathrm{~S}_{4}$, the OD character and the question of its polytypism. Z. Krist.-Cryst. Mater. 2012, 227, 468-475.

133. Harris, D.C.; Roberts, A.C.; Criddle, A.J. Vaughanite $\left(\mathrm{TlHgSb}_{4} \mathrm{~S}_{7}\right)$, a new mineral from the Hemlo gold deposit, Hemlo, Ontario, Canada. Mineral. Mag. 1989, 53, 79-83. [CrossRef]

134. Takéuchi, Y.; Ghose, S.; Nowacki, W. The crystal structure of hutchinsonite, $(\mathrm{Tl}, \mathrm{Pb})_{2} \mathrm{As}_{5} \mathrm{~S}_{9}$. Z. Krist.-Cryst. Mater. 1965, 121, 321-348.

135. Balić-Žunić, T.; Makovicky, E. Contributions to the crystal chemistry of thallium sulphosalts I: The O-D nature of imhofite. Neues Jahrb. Mineral. Abh. 1993, 165,317-330.

136. Ohmasa, M.; Nowacki, W. The crystal structure of vrbaite, $\mathrm{Hg}_{3} \mathrm{Tl}_{4} \mathrm{As}_{8} \mathrm{Sb}_{2} \mathrm{~S}_{20}$. Z. Krist.-Cryst. Mater. 1971, 134, 360-380.

137. Hålenius, U.; Hatert, F.; Pasero, M.; Mills, S.J. IMA Commission on New Minerals, Nomenclature and Classification (CNMNC) Newsletter 33. Mineral. Mag. 2016, 80, 1136.

138. Takéuchi, Y.; Ohmasa, M. The crystal structure of wallisite, PbTlCuAs${ }_{2} \mathrm{~S}_{5}$, the $\mathrm{Cu}$ analogue of hatchite PbTlAgAs $2 \mathrm{~S}_{5}$. Z. Krist.-Cryst. Mater. 1968, 127, 349-365. [CrossRef]

139. Dickson, F.W.; Radtke, A.S. Weissbergite, $\mathrm{TlSbS}_{2}$, a new mineral from the Carlin gold deposit, Nevada. Am. Mineral. 1978, 63, 720-724.

140. Cvetković, L.; Boronikhin, V.A.; Pavićević, M.K.; Krajnović, D.; Gržetić, I.; Libowitzky, E.; Tillmanns, E. Jankovićite, $\mathrm{Tl}_{5} \mathrm{Sb}_{9}(\mathrm{As}, \mathrm{Sb})_{4} \mathrm{~S}_{22}$, a new Tl-sulfosalt from Allchar, Macedonia. Miner. Petrol. 1995, 53, 125-131. [CrossRef]

141. Johan, Z.; Udubasa, G.; Zemann, J. "Monsmedite”, a discredited potassium thallium sulphate mineral from Baia Sprie and its identity with voltaite: The state of the art. Neues Jahrb. Mineral. Abh. 2009, 186, 63-66. [CrossRef]

142. Bourgoin, V.; Favreau, G.; Boulliard, J.C. Jas Roux: Un gisement exceptionnel à minéraux de thallium. Cah. Micromon. 2011, 3, 2-91.

143. Makreski, P.; Stefov, S.; Pejov, L.; Jovanovski, G. Minerals from Macedonia. XXIX. Experimental and theoretical study of the vibrational spectra of extremely rare Tl-sulfate mineral from Allchar-Dorallcharite. Vib. Spectrosc. 2017, 89, 85-91. [CrossRef]

144. Kovács-Pálffy, P.; Muske, J.; Földváric, M.; Kónyac, M.; Homonnayc, Z.; Ntaflosc, T.; Papp, G.; Király, E.; Sajó, I.; Szilágyi, V.; et al. Detailed study of "monsmedite" specimens from the original (1963) find, Baia Sprie, Baia Mare ore district (Romania). Carpathian J. Earth Environ. Sci. 2011, 6, 321-330.

145. Lin, J.; Yin, M.; Wang, J.; Liu, J.; Tsang, D.C.; Wang, Y.; Chen, Y. Geochemical fractionation of thallium in contaminated soils near a large-scale Hg-Tl mineralised area. Chemosphere 2020, 239, 124775. [CrossRef]

146. Long, D.; Fegan, N.E.; McKee, J.D.; Lyons, W.B.; Hines, M.E.; Macumber, P.G. Formation of alunite, jarosite and hydrous iron oxides in a hypersaline system: Lake Tyrrell, Victoria, Australia. Chem. Geol. 1992, 96, 183-202. [CrossRef]

147. Smeaton, C.M.; Fryer, B.J.; Weisener, C.G. Intracellular precipitation of Pb by Shewanella putrefaciens CN32 during the reductive dissolution of Pb-jarosite. Environ. Sci. Technol. 2009, 43, 8091-8096. [CrossRef]

148. Smith, A.M.L.; Dubbin, W.E.; Wright, K.; Hudson-Edwards, K.A. Dissolution of lead- and lead-arsenic-jarosites at pH 2 and 8 and 20 degrees C: Insights from batch experiments. Chem. Geol. 2006, 229, 344-361. [CrossRef]

149. Weisener, C.G.; Babechuk, M.G.; Fryer, B.J.; Maunder, C. Microbial dissolution of silver jarosite: Examining its trace metal behaviour in reduced environments. Geomicrobiol. J. 2008, 25, 415-424. [CrossRef]

150. Bingjie, O.; Xiancai, L.; Huan, L.; Juan, L.; Tingting, Z.; Xiangyu, Z.; Jianjun, L.; Rucheng, W. Reduction of jarosite by Shewanella oneidensis MR-1 and secondary mineralization. Geochim. Cosmochim. Acta 2014, 124, 54-71. [CrossRef]

151. Bao, Y.; Guo, C.; Lu, G.; Yi, X.; Wang, H.; Dang, Z. Role of microbial activity in Fe(III) hydroxysulfate mineral transformations in an acid mine drainage-impacted site from the Dabaoshan mine. Sci. Total Environ. 2018, 616, 647-657. [CrossRef]

152. Gao, K.; Jiang, M.; Guo, C.; Zeng, Y.; Fan, C.; Zhang, J.; Reinfelder, J.R.; Huang, W.; Lu, G.; Dang, Z. Reductive dissolution of jarosite by a sulfate reducing bacterial community: Secondary mineralization and microflora development. Sci. Total Environ. 2019, 690, 1100-1109. [CrossRef] [PubMed]

153. Yang, Y.; Chen, S.; Yang, D.; Zhang, W.; Wang, H.; Zeng, R. Anaerobic reductive bio-dissolution of jarosites by Acidithiobacillus ferrooxidans using hydrogen as electron donor. Sci. Total Environ. 2019, 686, 869-877. [CrossRef]

154. Casiot, C.; Egal, M.; Bruneel, O.; Verma, N.; Parmentier, M.; Elbaz-Poulichet, F. Predominance of aqueous Tl (I) species in the river system downstream from the abandoned Carnoulès mine (Southern France). Environ. Sci. Technol. 2011, 45, 2056-2064. [CrossRef]

155. Singer, P.C.; Stumm, W. Acidic mine drainage: The rate- determining step. Science 1970, 167, 1121-1123. [CrossRef] [PubMed]

156. Bigham, J.M.; Nordstrom, D.K. Iron and aluminum hydroxysulfates from acid sulfate waters. Rev. Mineral. Geochem. 2000, 40, 351-403. [CrossRef]

157. Gu, X.; Heaney, P.J.; Reis, F.D.A.; Brantley, S.L. Deep abiotic weathering of pyrite. Science 2020, 370, 1-8. [CrossRef] [PubMed] 